Article

\title{
Flower-like 3D CuO microsphere acting as photocatalytic water oxidation catalyst
}

\author{
Xiaoqiang Du a , Jingwei Huang a, Yingying Feng a, Yong Ding a,b,* \\ a Key Laboratory of Nonferrous Metal Chemistry and Resources Utilization of Gansu Province, State Key Laboratory of Applied Organic Chemistry and \\ College of Chemistry Chemical Engineering, Lanzhou University, Lanzhou 730000, Gansu, China \\ b State Key Laboratory for Oxo Synthesis and Selective Oxidation, Lanzhou Institute of Chemical Physics, Chinese Academy of Sciences, Lanzhou 730000, \\ Gansu, China
}

\section{A R T I C L E I N F O}

\section{Article history:}

Received 29 October 2015

Accepted 7 November 2015

Published 5 January 2016

Keywords:

Photocatalysis

Water oxidation

Metal catalyst

CuO microsphere

Stability

\author{
A B S T R A C T
}

Flower-like 3D CuO microspheres were synthesized and used to photo-catalyze water oxidation under visible light. The structure of the $\mathrm{CuO}$ microspheres was characterized by scanning electron microscopy, transmission electron microscopy, infrared, powder X-ray diffraction, electron dispersive spectroscopy, Raman and X-ray photoelectron spectroscopy (XPS). This is the first time that a copper oxide was demonstrated as a photocatalytic water oxidation catalyst under near neutral conditions. The catalytic activity of $\mathrm{CuO}$ microspheres in borate buffer shows the best performance with $\mathrm{O}_{2}$ yield of $11.5 \%$. No change in the surface properties of $\mathrm{CuO}$ before and after the photocatalytic reaction was seen by XPS, which showed good catalyst stability. A photocatalytic water oxidation reaction mechanism catalyzed by the $\mathrm{CuO}$ microspheres was proposed.

(C) 2016, Dalian Institute of Chemical Physics, Chinese Academy of Sciences. Published by Elsevier B.V. All rights reserved.

\section{Introduction}

Artificial photosynthesis to directly convert light energy into chemical energy currently attracts much interest in both fundamental study and applications [1-5]. The terminal step in Photosystem II (PSII) and a possible half-reaction for artificial photosynthesis is water oxidation,

$$
2 \mathrm{H}_{2} \mathrm{O} \rightarrow \mathrm{O}_{2}+4 \mathrm{H}^{+}+4 \mathrm{e}^{-} \quad E=1.23 \mathrm{~V}
$$

which is a challenging reaction [6-8] that is a significant mechanistic challenge in its requirements for extracting both electrons and protons to reduce protons or other chemicals to produce fuel and $\mathrm{O}-\mathrm{O}$ bond formation. Much effort has been devoted to identify new catalysts made of cheap and abundant materials for water oxidation, to integrate them into photosynthetic schemes. Water oxidation catalysts that contain common metals such as Co [9-24], Mn [25-28], Fe [29-32], Cu
[33-38], V [39], and Ni [40-46] have been studied under photo- and electrochemical conditions. Among the first row transition metal (TM) elements, $\mathrm{Cu}$ is the eighth most abundant element in the Earth's crust and Cu-based materials have been suggested for water oxidation catalysts (WOCs) for both their well-defined coordination chemistry and useful redox chemistry. However, little success has been achieved in the search for an efficient $\mathrm{Cu}$-based WOCs. No $\mathrm{CuO}$ has been reported as a photocatalytic water oxidation catalyst yet.

Copper complexes in the higher oxidation state are well-known catalysts for oxidizing organic compounds such as alcohols, phenols and hydrocarbon. The use of $\mathrm{Cu}$ for water oxidation has been much less explored. Recently, Mayer et al. [33] reported the first example of a homogeneous copper electrocatalyst for water oxidation. Meyer et al. [47] reported that simple $\mathrm{Cu}(\mathrm{II})$ salts were highly robust and sustainable electro-

\footnotetext{
* Corresponding author. Tel: +86-931-8912585; E-mail: dingyong1@lzu.edu.cn This work was supported by the National Natural Science Foundation of China $(21173105,21172098)$. 
catalytic water oxidation catalysts. Lin et al. [37] produced a highly active electrocatalytic water oxidation catalyst by simply mixing a $\mathrm{Cu}(\mathrm{II})$ salt and 6,6-dihydroxy-2,2-bipyridine $\left(\mathrm{H}_{2} \mathrm{~L}\right)$ in a basic aqueous solution. Sun et al. [36] prepared a robust electrocatalytic water oxidation catalyst based on copper oxide by facile electrodeposition of $\mathrm{Cu}^{2+}$ from borate buffer solution under near neutral conditions. However, it is still a continuing challenge to design efficient, easily accessible, and stable catalysts for the photocatalytic water oxidation reaction that is based on the common copper metal.

Here, flower-like three dimensional (3D) $\mathrm{CuO}$ microspheres were easily prepared from a $\mathrm{Cu}\left(\mathrm{NO}_{3}\right)_{2} \cdot 3 \mathrm{H}_{2} \mathrm{O}$ precursor. We report on the photoinduced water oxidation obtained by using a sacrificial system made of $\left[\mathrm{Ru}(\mathrm{bpy})_{3}\right]^{2+}\left(\mathrm{bpy}=2,2^{\prime}\right.$-bipyridine) as a photosensitizer, $\mathrm{Na}_{2} \mathrm{~S}_{2} \mathrm{O}_{8}$ as the sacrificial acceptor, and the flower-like 3D CuO microspheres as the photocatalytic water oxidation catalyst. The catalytic activity of the $\mathrm{CuO}$ microspheres in borate buffer showed a best performance of a TOF of $0.21 \mu \mathrm{mol} \mathrm{s} \mathrm{s}^{-1} \mathrm{~m}^{-2}$. Our data clearly demonstrated that the evolved 0 originated exclusively from the water. We suggest that the catalytic activity for $\mathrm{O}_{2}$ evolution can be related to the enhanced specific surface area of $\mathrm{CuO}$.

\section{Experimental}

\subsection{Synthesis of $\mathrm{CuO}$ microspheres}

$\mathrm{H}_{2}{ }^{18} \mathrm{O}\left(97 \%{ }^{180}\right)$ was purchased from Mashall Isotope Ltd. Purified water $(18.2 \mathrm{M} \Omega \cdot \mathrm{cm})$ for the preparation of the solutions was obtained from Molecular Lab Water Purifier, and all other chemicals and salts used were of the highest purity available from commercial sources. All chemicals were of analytical grade and used without further purification. In a typical synthesis, $1 \mathrm{~g}$ of block polymer P123 was dissolved in $40 \mathrm{~mL}$ distilled water. $\mathrm{Cu}\left(\mathrm{NO}_{3}\right)_{2} \cdot 3 \mathrm{H}_{2} \mathrm{O}(0.005 \mathrm{~mol})$ was added to the solution and this mixture was stirred until a clear blue solution was formed. Then, ammonia solution (10 mL, 25-28 wt\%) was added, which was followed by the formation of a dark blue solution. The resulting dark blue mixture was stirred for $1 \mathrm{~h}$, transferred into a $100 \mathrm{~mL}$ three-necked flask, and refluxed at $110{ }^{\circ} \mathrm{C}$ for $2 \mathrm{~h}$. Vigorous stirring was maintained throughout the process. After the reaction, the system was cooled naturally to room temperature. Precipitates were collected by centrifugation and washed several times with deionized water and ethanol. The resulting precipitates were dried at $80{ }^{\circ} \mathrm{C}$ (yield $0.2 \mathrm{~g}, 41 \%)$.

\subsection{Photocatalytic water oxidation}

Photocatalytic water oxidation was performed as follows. The desired concentration of catalyst $0.5 \mathrm{~g} / \mathrm{L}$ was added to a buffer solution ( $80 \mathrm{mmol} / \mathrm{L}$, pH 8.5 for borate buffer) containing $\left[\mathrm{Ru}(\text { bpy) })_{3}\right] \mathrm{Cl}_{2}(1.0 \mathrm{mmol} / \mathrm{L})$ and $\mathrm{Na}_{2} \mathrm{~S}_{2} \mathrm{O}_{8}(5.0 \mathrm{mmol} / \mathrm{L})$. The above solution was deaerated by purging with Ar gas for 10 min in a flask $(28 \mathrm{~mL}$ ) sealed with a rubber septum (the volume of the reaction solution was $15 \mathrm{~mL}$ ). The reaction was then started by irradiating the solution with a LED light source (light intensity $16 \mathrm{~mW}$, beam diameter $2 \mathrm{~cm}$ ) (Fig. S1) through a transmitting glass filter $(\lambda \geq 420 \mathrm{~nm})$ at room temperature. After each irradiation time, $150 \mu \mathrm{L}$ of Ar was injected into the flask and then the same volume of gas in the headspace of the flask was withdrawn by a SGE gas-tight syringe and analysed by gas chromatography (GC). The $\mathrm{O}_{2}$ in the sampled gas was separated by passing through a packed molecular sieve $5 \mathrm{~A}$ column ( $2 \mathrm{~m} \times 3 \mathrm{~mm}$ ) with an Ar carrier gas and quantified by a thermal conductivity detector (TCD, Shimadzu GC-9A). The total amount of evolved $\mathrm{O}_{2}$ was calculated from the concentration of $\mathrm{O}_{2}$ in the headspace gas. Contamination of the head-space with air was corrected by measuring of $\mathrm{N}_{2}$ present in the head-space (from the $\mathrm{N}_{2}$ peak in the GC traces). The solution $\mathrm{pH}$ was measured after the reaction by a METTLER TOLEDO FEP20 pH meter.

\subsection{Characterization technique}

X-ray photoelectron spectra (XPS) were measured by ESCALAB250xi with X-Ray monochromatisation. GC-MS spectral analyses of isotopic labelled $\mathrm{O}_{2}$ were performed on an Agilent Series Model 7890A chromatograph interfaced with an Agilent Series Model 5975C mass spectrometer. X-ray diffraction (XRD) data were collected with a PANalytical X'Pert Pro Diffractometer operated at $40 \mathrm{kV}$ and $40 \mathrm{~mA}$ with $\mathrm{Cu} K_{\alpha}$ radiation (step size: $0.017^{\circ}$, step time: $10.34 \mathrm{~s}$ ). Scanning electron microscopy (SEM) observations were performed on a Hitachi S-4800 microscope operated at an accelerating voltage of 5.0 $\mathrm{kV}$. Transmission electron microscopy (TEM) images were obtained with a JEOL JEM-2010 instrument operated at $200 \mathrm{kV}$. $\mathrm{N}_{2}$ adsorption at $-196{ }^{\circ} \mathrm{C}$ was performed with a Micromeritics ASAP 2020M system. A sample mass of about $100 \mathrm{mg}$ was used for the adsorption analysis after pretreatment at $80^{\circ} \mathrm{C}$ for $8.0 \mathrm{~h}$ under vacuum conditions and kept in $\mathrm{N}_{2}$ atmosphere until the $\mathrm{N}_{2}$ adsorption measurement. The surface area was calculated using Langmuir and Brunauer-Emmett-Teller (BET) method.

\subsection{Electrochemistry}

Cyclic voltammetry (CV) was recorded on a CHI660D electrochemical analyser. A glassy carbon, an $\mathrm{Ag} / \mathrm{AgCl}$ and a Pt wire electrodes were used as a working, reference and auxiliary electrodes, respectively. CV was obtained in buffer solutions at room temperature with a scanning rate of $100 \mathrm{mV} / \mathrm{s}$.

\subsection{Isotope-labeled experiment}

The 10.8 atom $\% \mathrm{H}_{2}{ }^{18} \mathrm{O}$ of borate buffer solution $(\mathrm{pH} 8.5,80$ $\mathrm{mmol} / \mathrm{L})$ containing $\mathrm{CuO}(0.5 \mathrm{~g} / \mathrm{L}),\left[\mathrm{Ru}(\mathrm{bpy})_{3}\right] \mathrm{Cl}_{2}(1.0 \mathrm{mmol} / \mathrm{L})$, $\mathrm{Na}_{2} \mathrm{~S}_{2} \mathrm{O}_{8}(5.0 \mathrm{mmol} / \mathrm{L})$ was deaerated with Helium gas before irradiation by LED light $(\lambda \geq 420 \mathrm{~nm})$ in a flask that is sealed with a rubber septum. After $9 \mathrm{~min}, 50 \mu \mathrm{L}$ of gas sample was withdrawn using a gas-tight syringe for gas analysis. An Agilent Series 7890A model chromatograph interfaced with an Agilent Series 5975C model mass spectrometer operating in electron impact ionization mode was used to collect mass spectrometric data. The MS detector was tuned for maximum sensitivity 
(quadruple temperature, $150{ }^{\circ} \mathrm{C}$; ion source temperature, 230 $\left.{ }^{\circ} \mathrm{C}\right)$. The single ion mode was used to scan for the ions $m / z=28$, $32,34,36$ with a dwell time of $100 \mathrm{~ms}$, resulting in 8.3 cycles per second. The ions of $\mathrm{m} / \mathrm{z}$ range from 30 to 50 were also scanned in order to observe the abundance change of $160^{18} \mathrm{O}$ and ${ }^{18} \mathrm{O}^{18} \mathrm{O}$, which evolved from $\mathrm{H}_{2}{ }^{16} \mathrm{O}$ and $\mathrm{H}_{2}{ }^{18} \mathrm{O}$, respectively. The total flow rate into the spectrometer was limited to 0.6 $\mathrm{mL} / \mathrm{min}$. The GC equipped with a molecular sieve column (30 $\mathrm{m} \times 0.32 \mathrm{~mm} \times 15 \mu \mathrm{m}$ ), and the vaporizing chamber temperature and column temperature was set for 100 and $35{ }^{\circ} \mathrm{C}$, respectively.

\section{Results and discussion}

\subsection{Characterization of $\mathrm{CuO}$ microspheres}

CuO microspheres were synthesized by a modified literature method [48]. The morphology of the synthesized $\mathrm{CuO}$ microspheres was examined by SEM and TEM. Fig. 1(a) shows typical SEM image of the synthesized $\mathrm{CuO}$ microspheres. It showed a quite uniform microsphere structure with an average diameter of about $2.0 \mu \mathrm{m}$. In Fig. 1(b), the morphology of the $\mathrm{CuO}$ microsphere material is seen to be self-assembled radially comprising many nanoplates with a thickness of about $25 \mathrm{~nm}$. Fig. 1(c) shows a typical TEM image of the $\mathrm{CuO}$ spheres. To confirm the formation of $\mathrm{CuO}$, the material was characterized by powder XRD (Fig. 1(d)). All the peaks of the CuO microspheres can be assigned to monoclinic symmetry of CuO (JCPDS 05-0661). The main peaks were located at $2 \theta=32.6^{\circ}, 35.6^{\circ}$, $38.7^{\circ}, 48.7^{\circ}, 53.4^{\circ}, 58.3^{\circ}, 61.6^{\circ}, 66.2^{\circ}, 68.2^{\circ}, 72.4^{\circ}$ and $75.1^{\circ}$, which correspond, respectively, to the (110), (-111), (111), (-202), (020), (202), (-113), (-311), (220), (311) and (-222) planes of monoclinic CuO. No impurity peak was observed, indicating the high purity of the prepared samples. The broad XRD peaks also indicated the sample was composed of $\mathrm{CuO}$ nanocrystallines. The electron dispersive spectroscopy (EDS, Fig. S2) spectrum further confirmed the existence of $\mathrm{Cu}$ and $\mathrm{O}$ in the composites. The crystal structure and coordination mode of monoclinic $\mathrm{CuO}$ are shown in Fig. 2(a) and (b). The $\mathrm{Cu}-\mathrm{O}$
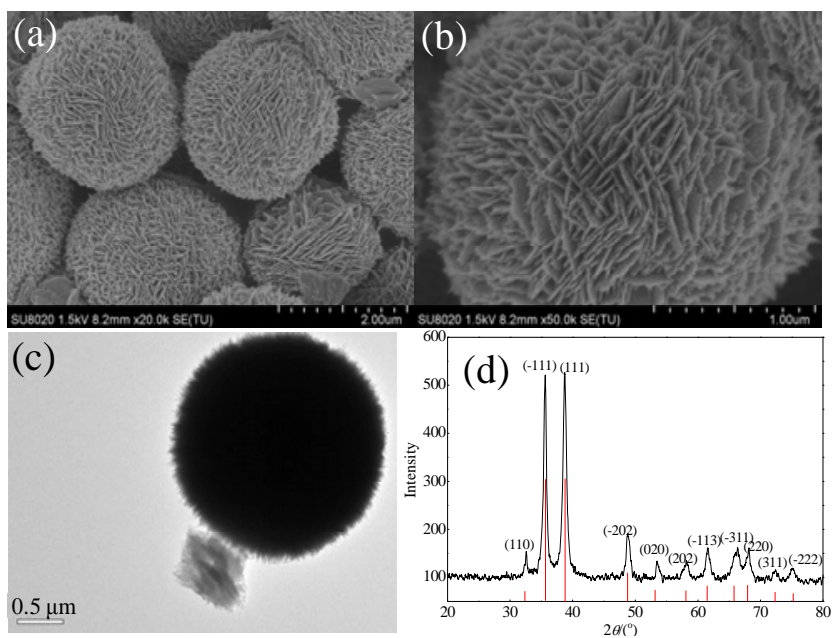

Fig. 1. SEM images $(a, b)$, TEM image (c), and XRD pattern (d) of $\mathrm{CuO}$ microspheres.

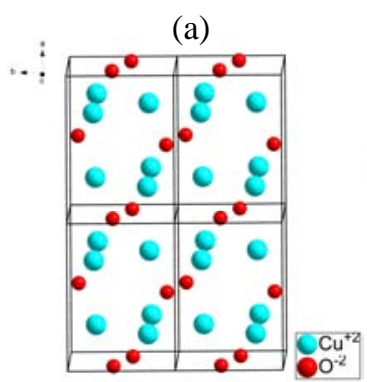

(b)

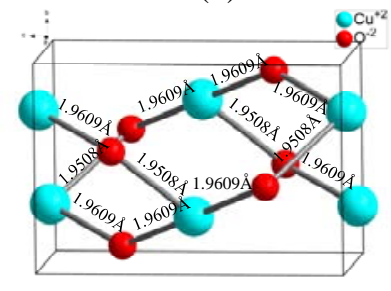

Fig. 2. Crystal structure of monoclinic $\mathrm{CuO}$ (a) and its coordination mode (b).

distance was 1.95 and $1.96 \AA$ A. FT-IR spectrum also confirmed that the prepared $\mathrm{CuO}$ samples are a pure phase of $\mathrm{CuO}$ with the monoclinic structure (Fig. S3). Raman spectrum also confirmed that $\mathrm{CuO}$ samples are a pure phase (Fig. S4). The composition and valence states of the $\mathrm{CuO}$ were further investigated by XPS (Fig. S5). XPS (Fig. S5(a)) detected the $\mathrm{Cu} 2 p_{3 / 2}$ peaks at $933.7 \mathrm{eV}$ with two satellite peaks at 941.0 and $943.5 \mathrm{eV}$ and $\mathrm{Cu} 2 p_{1 / 2}$ peaks at $953.7 \mathrm{eV}$ with a satellite peak at $962.5 \mathrm{eV}$, respectively. These features correspond to a $\mathrm{Cu}^{2+}$ state for the $\mathrm{Cu}$ atoms. As shown in Fig. S5(b), the $01 s$ core level spectrum was broad, and two peaks (marked as I and II) were observed. Peak I at the lower energy of $529.6 \mathrm{eV}$ is in agreement with that for $\mathrm{O}^{2-}$ in $\mathrm{CuO}$, while peak II at the higher energy of $531.4 \mathrm{eV}$ was attributed to oxygen adsorbed on the surface of the $\mathrm{CuO}$ microspheres. The XPS results further support the conclusion that the sample is pure $\mathrm{CuO}$.

\subsection{Electrochemical properties}

The cyclic voltammogram of the $\mathrm{CuO}$ microspheres in a $\mathrm{pH}$ 5.8 buffer solution showed a catalytic water oxidation peak (the reference current was zero) at $1.82 \mathrm{~V}$ vs. RHE (Fig. 3(a)). This potential was much higher than the potential of the oxidized state of $\left[\mathrm{Ru}(\mathrm{bpy})_{3}\right]^{2+/ 3+}\left(E_{1 / 2}=1.67 \mathrm{~V}\right.$ vs. RHE). Consequently, light driven water oxidation by $\mathrm{CuO}$ microspheres using $\left[\mathrm{Ru}(\mathrm{bpy})_{3}\right]^{2+}$ as a photosensitizer was thermodynamically unfavored in a pH 5.8 buffer solution. Water oxidation is favoured under basic conditions. Therefore, the $\mathrm{CuO}$ microspheres were potentially useful for water oxidation under near neutral conditions. The electrochemical properties of the $\mathrm{CuO}$ microspheres were investigated in $\mathrm{pH} 8.5$ borate buffer solutions (Fig. 3(b)). A catalytic water oxidation curve began from $1.72 \mathrm{~V}$ vs. RHE, which were $0.10 \mathrm{~V}$ vs. RHE lower than that observed in a pH 5.8 buffer solutions. In contrast, only the minimum current was obtained in the same buffered solution without the CuO microspheres (Fig. 3(b)). Most importantly, the catalytic potential of the $\mathrm{CuO}$ microspheres was lower than that of $\left[\mathrm{Ru}(\mathrm{bpy})_{3}\right]^{2+/ 3+}$, which indicated that $\left[\mathrm{Ru}(\mathrm{bpy})_{3}\right]^{2+/ 3+}$ could drive the $\mathrm{CuO}$ microspheres to oxidize water.

\subsection{Catalytic behaviour of the CuO microspheres for photocatalytic water oxidation}

Light-driven water oxidation was performed by the photoirradiation $(\lambda \geq 420 \mathrm{~nm})$ of a borate buffer $(80 \mathrm{mmol} / \mathrm{L}, \mathrm{pH}$ 

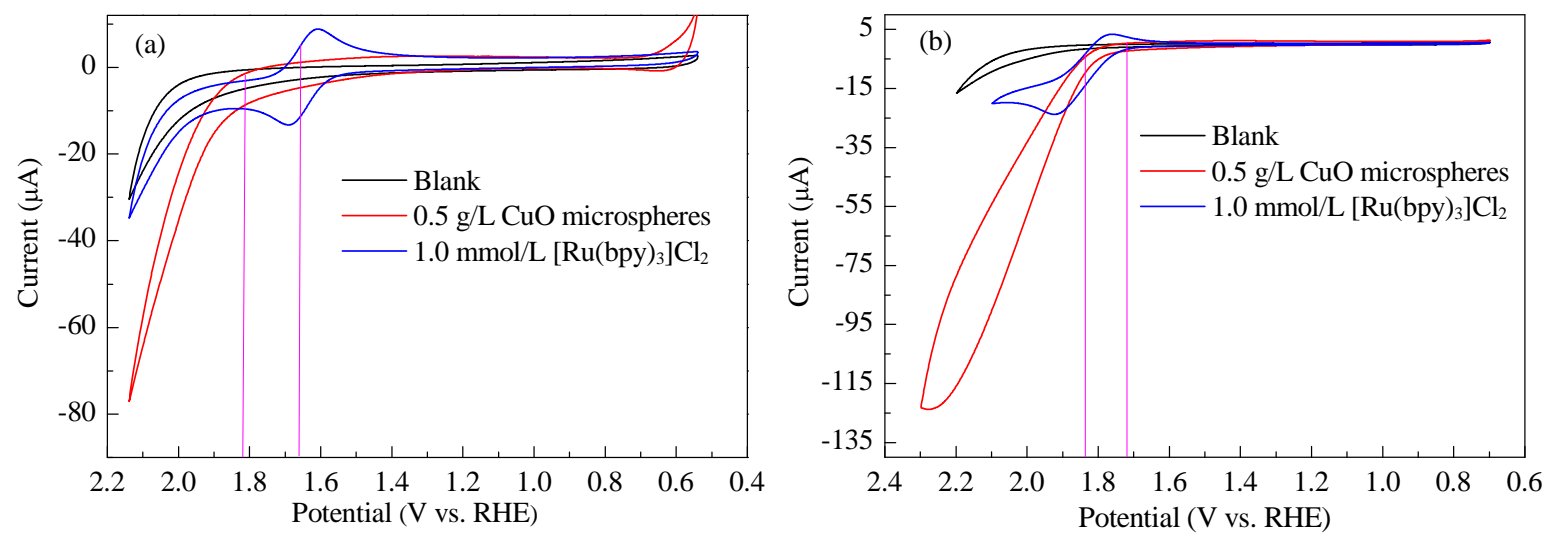

Fig. 3. (a) CVs of $80 \mathrm{mmol} / \mathrm{L}$ sodium $\mathrm{Na}_{2} \mathrm{SiF}_{6}+\mathrm{NaHCO}_{3}$ solution at pH 5.8 using $0.5 \mathrm{~g} / \mathrm{L} \mathrm{CuO}$ microspheres and $1.0 \mathrm{mmol} / \mathrm{L}\left[\mathrm{Ru}(\mathrm{bpy})_{3}\right] \mathrm{Cl}$. (b) $\mathrm{CVs}$ of $80 \mathrm{mmol} / \mathrm{L}$ sodium borate buffer solution at $\mathrm{pH} 8.5$ with $0.5 \mathrm{~g} / \mathrm{L}$ of $\mathrm{CuO}$ microspheres and $1.0 \mathrm{mmol} / \mathrm{L}$ of $\left[\mathrm{Ru}(\mathrm{bpy})_{3}\right] \mathrm{Cl}_{2}$.

8.0-9.5, $15 \mathrm{~mL}$ ) containing the metal oxide catalyst, $\mathrm{Na}_{2} \mathrm{~S}_{2} \mathrm{O}_{8}$ as the sacrificial electron acceptor, and $\left[\mathrm{Ru}(\mathrm{bpy})_{3}\right] \mathrm{Cl}_{2}$ as the photosensitizer. The catalytic cycle of this visible light-driven water oxidation is depicted in Scheme S1. Isotope-labelled water oxidation experiments using ${ }^{180} \mathrm{O}$-enriched water $(10.8 \%)$ instead of $\mathrm{H}_{2}{ }^{16} \mathrm{O}$ were carried out with the $\mathrm{CuO}$ microsphere catalyst to confirm that the water was the source of the evolved oxygen. The relative abundance of oxygen isotopes, which were determined from the intensities of their three molecular ion peaks, is listed on Fig. S6. The ratio of $160^{16} 0:{ }^{16} 0^{18} 0: 180^{18} 0$ was determined to be $81: 18: 1$, which is in good agreement with the simulated ratio of 80:19:1 when the oxygen comes exclusively from the water. The data clearly demonstrated that the evolved 0 originated exclusively from the water.

\subsubsection{Effect of $p H$}

Water oxidation is $\mathrm{pH}$ dependent and the catalytic activity of the $\mathrm{CuO}$ microspheres was studied under different $\mathrm{pH}$ conditions (Fig. 4). The reaction at $\mathrm{pH} 8.5$ showed the highest $\mathrm{O}_{2}$ yield and turnover frequency (TOF). The $\mathrm{O}_{2}$ yield and TOF decreased with increasing $\mathrm{pH}$ from 8.5 to 9.5. Although a high $\mathrm{pH}$ is thermodynamically favourable for water oxidation, a higher $\mathrm{pH}$ can also accelerate the degradation of the photosensitizer, which is a competitive process in the reduction of $\left[\mathrm{Ru}(\mathrm{bpy})_{3}\right]^{3+}$ to $\left[\mathrm{Ru}(\mathrm{bpy})_{3}\right]^{2+}[10,49,50]$. When $\mathrm{pH} 9.0$ and 9.5 were used, the orange red colour of the fresh reaction solution turned much darker after $\mathrm{O}_{2}$ evolution stopped. The higher $\mathrm{pH}$ value promoted the degradation of the photosensitizer by the nucleophilic attack of water or $\mathrm{OH}^{-}$on $\left[\mathrm{Ru}(\mathrm{bpy})_{3}\right]^{3+}$ before the photocatalytic water oxidation. This was supported by UV-vis evidence (Figs. S7 and S8). When the pH 8.0 buffer was used, the $\mathrm{O}_{2}$ evolution and TOF also decreased relative to that of the $\mathrm{pH}$ 8.5 buffer. The orange red color of the fresh reaction solution turned green (Fig. S9) after $30 \mathrm{~s}$ of photoirradiation. The solution colour turned green with reaction time, demonstrating that there was a pile up of $\left[\mathrm{Ru}(\mathrm{bpy})_{3}\right]^{3+}$ and Eq. (2) became the rate determining step.

$$
4\left[\mathrm{Ru}(\text { bpy })_{3}\right]^{3+}+2 \mathrm{H}_{2} \mathrm{O} \rightarrow 4\left[\mathrm{Ru}(\mathrm{bpy})_{3}\right]^{2+}+\mathrm{O}_{2}+4 \mathrm{H}^{+}
$$

The presence of $\left[\mathrm{Ru}(\mathrm{bpy})_{3}\right]^{3+}$ was proved by UV-vis by its characteristic absorbance at $670 \mathrm{~nm}$ (Fig. S10). First, the exist- ence of accumulated $\left[\mathrm{Ru}(\mathrm{bpy})_{3}\right]^{3+}$ meant that a large amount of the water oxidation oxidant could not be effectually used in the catalytic cycle. Second, at $\mathrm{pH} 8.0$, the $\mathrm{pH}$ value of the reaction solution was measured to decrease to 2.7 after the reaction stopped as a result of the release of protons. This demonstrated that the acetic-alkali equilibrium was insufficient for maintaining a thermodynamically favourable $\mathrm{pH}$ value for photocatalytic water oxidation. Moreover, when $\mathrm{pH} 8.0$ was used, the time of $\mathrm{O}_{2}$ evolution stopped earlier. It achieved a plateau within $3 \mathrm{~min}$, which demonstrated that it was thermodynamically unfavorable in a pH 2.7 buffer solution. In other words, the light-driven water oxidation by the $\mathrm{CuO}$ microspheres using $\left[\mathrm{Ru}(\mathrm{bpy})_{3}\right]^{2+}$ as a photosensitizer was thermodynamically more favourable for photocatalytic water oxidation at higher $\mathrm{pH}$ values. These results indicated that $\mathrm{O}_{2}$ evolution depended on a combination of several factors, which include low $\mathrm{pH}$, electron acceptor consumption, photosensitizer (Fig. S11) and catalyst deactivation.

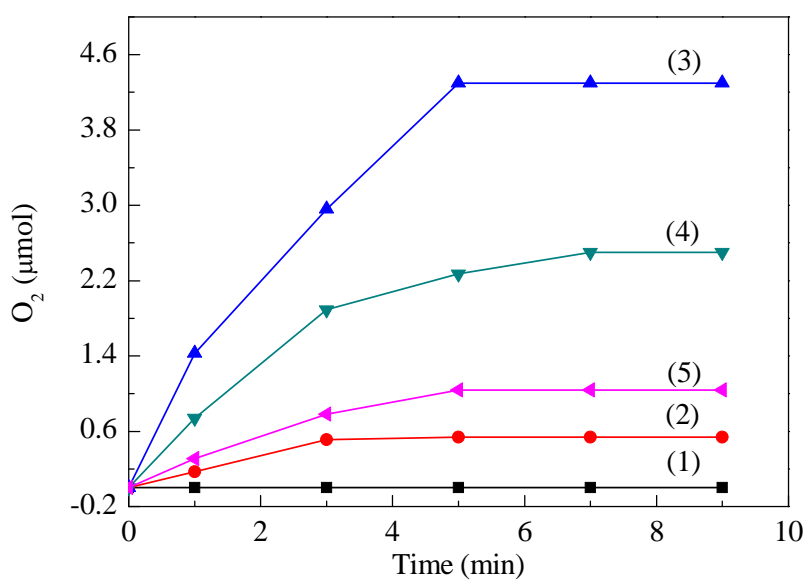

Fig. 4. Kinetics of $\mathrm{O}_{2}$ formation in the photocatalytic system under various $\mathrm{pH}$ conditions using $\mathrm{CuO}$ microspheres (1) $\mathrm{pH} 5.8$, $\mathrm{Na}_{2} \mathrm{SiF}_{6}+\mathrm{NaHCO}_{3}, 20 \mathrm{mmol} / \mathrm{L} ;$ (2) $\mathrm{pH} 8.0,80 \mathrm{mmol} / \mathrm{L} \mathrm{NaBi}$; (3) pH 8.5, $80 \mathrm{mmol} / \mathrm{L} \mathrm{NaBi}$; (4) pH 9.0, $80 \mathrm{mmol} / \mathrm{L} \mathrm{NaBi}$; (5) pH 9.5, $80 \mathrm{mmol} / \mathrm{L}$ $\mathrm{NaBi}$. Reaction conditions: LED lamp $(\lambda \geq 420 \mathrm{~nm})$, catalyst concentration $0.5 \mathrm{~g} / \mathrm{L},\left[\mathrm{Ru}(\mathrm{bpy})_{3}\right] \mathrm{Cl}_{2} 1.0 \mathrm{mmol} / \mathrm{L}, \mathrm{Na}_{2} \mathrm{~S}_{2} \mathrm{O}_{8} 5.0 \mathrm{mmol} / \mathrm{L}$, total reaction volume $15 \mathrm{~mL}$, overall volume $\sim 28 \mathrm{~mL}$, with vigorous agitation using a magnetic stirrer. 


\subsubsection{Effect of catalyst concentration}

The photocatalytic water oxidation was investigated with different concentrations of the $\mathrm{CuO}$ microspheres in $28 \mathrm{~mL}$ total volume. The catalytic performances are compared in Fig. 5. $\mathrm{O}_{2}$ rapidly formed after $1 \mathrm{~min}$ of visible light illumination, and the $\mathrm{O}_{2}$ evolution rate decreased with time (the slope of the curve became level with the lapse of time), and $\mathrm{O}_{2}$ evolution achieved a plateau in $11 \mathrm{~min}$. The reason is that the sacrificial electron acceptor of $\mathrm{Na}_{2} \mathrm{~S}_{2} \mathrm{O}_{8}$ was partially used up and the photosensitizer of $\left[\mathrm{Ru}(\mathrm{bpy})_{3}\right] \mathrm{Cl}_{2}$ was decomposed during the photocatalytic process, so the amount of $\mathrm{O}_{2}$ formation was limited. A maximum $\mathrm{O}_{2}$ evolution yield (yield was defined as twice the number of moles of $\mathrm{O}_{2}$ per mole of $\mathrm{Na}_{2} \mathrm{~S}_{2} \mathrm{O}_{8}$ ) of $11.5 \%$ and $\mathrm{O}_{2}$ evolution amount of $4.4 \mu \mathrm{mol}$ were obtained when the concentration of the $\mathrm{CuO}$ microspheres was $0.5 \mathrm{~g} / \mathrm{L}$. The $\mathrm{O}_{2}$ yield increased with the catalyst concentration up to $1.0 \mathrm{~g} / \mathrm{L}$. The yield for $\mathrm{O}_{2}$ evolution increased to $12.0 \%$, and decreased with a lower catalyst concentration of $0.25 \mathrm{~g} / \mathrm{L}$. The yield for $\mathrm{O}_{2}$ evolution decreased to $5.7 \%$. Moreover, the TOF decreased from $2.5 \times 10^{-4}$ to $2.1 \times 10^{-4}$ and $0.9 \times 10^{-4} \mathrm{~s}^{-1}$ per $\mathrm{Cu}$. The amount of $\mathrm{O}_{2}$ increased with catalyst concentration, but it reached saturation at $1.0 \mathrm{~g} / \mathrm{L}$.

\subsubsection{Effect of different buffers}

The visible light-driven water oxidation catalyzed by the $\mathrm{CuO}$ microspheres was investigated in different buffers: borate buffer (pH 8.5, $80 \mathrm{mmol} / \mathrm{L}$ ) and phosphate buffer (pH 8.5, 80 $\mathrm{mmol} / \mathrm{L}$, Figs. S12 and S13). The catalytic activity of the CuO microspheres in borate buffer showed the highest catalytic activity with an $\mathrm{O}_{2}$ yield of $11.5 \%$. The $\mathrm{O}_{2}$ evolution yield decreased to $4.8 \%$ in the phosphate buffer $\left(\mathrm{H}_{2} \mathrm{PO}_{4}{ }^{-}\right.$and $\left.\mathrm{HPO}_{4}{ }^{2-}\right)$. When the phosphate buffer was used, the $\mathrm{pH}$ value of the reaction solution changed a lot after the oxygen evolution was completed. The final $\mathrm{pH}$ value was decreased to 6.5 with the phosphate buffer, whereas the final $\mathrm{pH}$ was decreased to 8.2 for the borate buffer. A lower amount of $\mathrm{O}_{2}$ evolution was observed for the reaction in the phosphate buffers. We think that this can be ascribed to its low acetic-alkali equilibrium because water oxidation is thermodynamically unfavourable under low

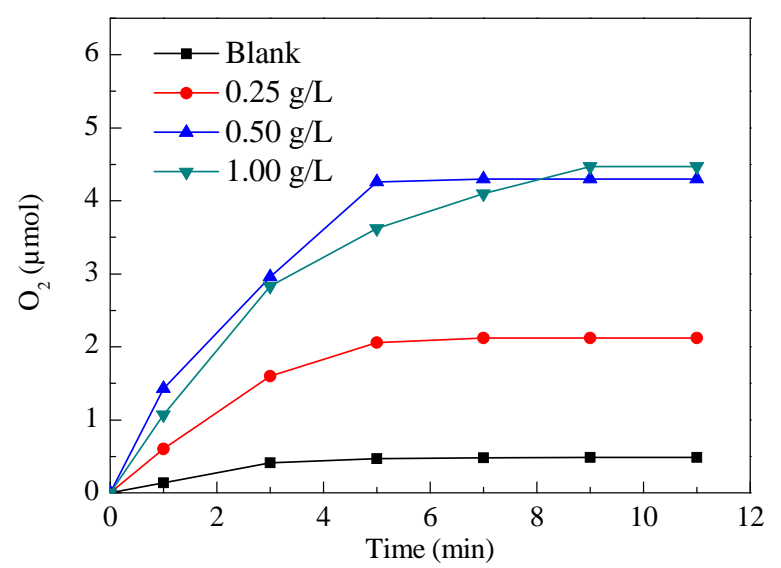

Fig. 5. Kinetics of $\mathrm{O}_{2}$ formation in the photocatalytic system using different concentrations of $\mathrm{CuO}$ microspheres. The other conditions were the same as in Fig. 4 (pH 8.5, $80 \mathrm{mmol} / \mathrm{L} \mathrm{NaBi}$ ).
pH conditions. In addition, phosphate accelerates the decomposition of $\left[\mathrm{Ru}(\mathrm{bpy})_{3}\right]^{3+}$ (Fig. S14).

\subsubsection{Control experiments}

To confirm that the oxygen evolved in the photocatalytic water oxidation reaction was indeed catalyzed by the $\mathrm{CuO}$ microspheres, several control experiments (Table S1) were used. (1) Under identical conditions without the photosensitizer, no oxygen was evolved in the presence of light (Fig. S15(2)), confirming that $\left[\mathrm{Ru}(\mathrm{bpy})_{3}\right]^{2+}$ is an essential ingredient for water oxidation in the photocatalytic system. (2) Without the $\mathrm{CuO}$ microspheres catalyst, little oxygen was generated in the presence of $\mathrm{Na}_{2} \mathrm{~S}_{2} \mathrm{O}_{8}$ and $\left[\mathrm{Ru}(\mathrm{bpy})_{3}\right] \mathrm{Cl}_{2}$ in a borate buffer ( $\mathrm{pH}$ 8.5) under photo-irradiation (Fig. S15(3)). The oxygen evolution amount is one-ninth that in the catalytic runs using $0.5 \mathrm{~g} / \mathrm{L} \mathrm{CuO}$ microspheres, indicating that the $\mathrm{CuO}$ microspheres were indeed involved in the catalytic oxygen evolution processes. (3) Without the sacrificial electron acceptor, no oxygen was generated in the presence of light (Fig. S15(1)), revealing that $\mathrm{Na}_{2} \mathrm{~S}_{2} \mathrm{O}_{8}$ is an essential ingredient for water oxidation in the photocatalytic system. (4) An irradiation control experiment showed that the catalytic oxygen evolution in the system was driven by light (Fig. S16). All these results clearly demonstrated that the light-driven water oxidation was catalyzed by the $\mathrm{CuO}$ microspheres.

\subsubsection{Photocatalytic water oxidation with different catalysts}

The time course of $\mathrm{O}_{2}$ evolution with different metal oxides is shown in Fig. 6. Table 1 displays the yield of $\mathrm{O}_{2}$ obtained from the metal oxides studied. A minimum amount of $\mathrm{O}_{2}$ evolution was detected in the absence of a catalyst. The yield of $\mathrm{O}_{2}$ evolution obtained after 9 min of photoirradiation with the $\mathrm{CuO}$ microspheres (11.5\%) was higher than those with $\mathrm{Cu}\left(\mathrm{NO}_{3}\right)_{2} \cdot 3 \mathrm{H}_{2} \mathrm{O}$ (10.7\%) and commercial CuO (2.1\%). The BET surface area $\left(A_{\mathrm{BET}}\right)$ of the $\mathrm{CuO}$ microspheres $\left(15 \mathrm{~m}^{2} / \mathrm{g}\right)$ was significantly higher (5 times) than that of the commercial $\mathrm{CuO}\left(3 \mathrm{~m}^{2} / \mathrm{g}\right)$. Clearly, the $\mathrm{CuO}$ microspheres have a superior catalytic activity to that of the commercial $\mathrm{CuO}$ under photocatalytic water oxidation. Jiao et al. [22] reported a novel method to synthesize

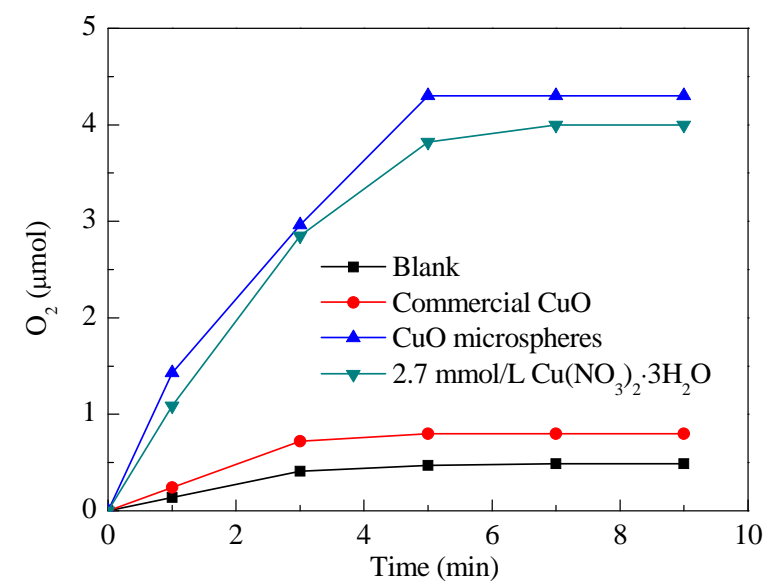

Fig. 6. Kinetics of $\mathrm{O}_{2}$ formation in the photocatalytic system using different catalysts. Other conditions were the same as in Fig. 4 (pH 8.5, 80 $\mathrm{mmol} / \mathrm{L} \mathrm{NaBi}$. 
Table 1

Water oxidation catalyzed by different catalysts.

\begin{tabular}{lcccc}
\hline Catalyst & $\begin{array}{c}A_{\mathrm{BET}} \\
\left(\mathrm{m}^{2} / \mathrm{g}\right)\end{array}$ & $\begin{array}{c}\mathrm{O}_{2} \text { yield } \\
(\%)\end{array}$ & $\begin{array}{c}\text { TOF a } \\
\left(\mu \mathrm{mol} \mathrm{s}^{-1} \mathrm{~m}^{-2}\right)\end{array}$ & $\begin{array}{c}\text { TOF b } \\
\left(\mathrm{s}^{-1} \text { per } \mathrm{Cu}\right)\end{array}$ \\
\hline CuO microspheres & 15 & 11.5 & 0.21 & $2.5 \times 10^{-4}$ \\
$\mathrm{Cu}\left(\mathrm{NO}_{3}\right)_{2} \cdot 3 \mathrm{H}_{2} \mathrm{O}^{\mathrm{c}}$ & - & 10.7 & - & - \\
Commercial CuO & 3 & 2.1 & 0.17 & $0.4 \times 10^{-4}$ \\
No catalyst & - & 1.4 & 0 & 0 \\
\hline
\end{tabular}

Reaction conditions: LED lamp $(\lambda \geq 420 \mathrm{~nm})$; catalyst concentration 0.5 $\mathrm{g} / \mathrm{L},\left[\mathrm{Ru}(\mathrm{bpy})_{3}\right] \mathrm{Cl}_{2} 1.0 \mathrm{mmol} / \mathrm{L}, \mathrm{Na}_{2} \mathrm{~S}_{2} \mathrm{O}_{8} 5.0 \mathrm{mmol} / \mathrm{L}$, sodium borate buffer $80 \mathrm{mmol} / \mathrm{L}$ (initial pH 8.5); total reaction volume $15 \mathrm{~mL}$, overall volume $\sim 28 \mathrm{~mL}$, with vigorous agitation using a magnetic stirrer. a Normalized by catalyst surface area for $\mathrm{O}_{2}$ evolution in one minute. b Based on the oxygen product rate (in $1 \mathrm{~min}$ ) divided by the $\mathrm{Cu}$ atoms in the catalyst.

c $2.7 \mathrm{mmol} / \mathrm{L}$ (equivalent to $0.5 \mathrm{~g} / \mathrm{L}$ ).

free unsupported ultra-small cobalt oxide nanometres materials by an in situ phase transformation approach with a layered $\mathrm{Co}(\mathrm{OH})\left(\mathrm{OCH}_{3}\right)$ precursor. The cobalt oxide with a particle size less than $2 \mathrm{~nm}$ gave a TOF of $0.023 \mathrm{~s}^{-1}$ per cobalt in photocatalytic water oxidation. However, $6 \mathrm{~nm} \mathrm{Co}_{3} \mathrm{O}_{4}$ nanoparticles gave a lower TOF of $0.002 \mathrm{~s}^{-1}$ per cobalt in photocatalytic water oxidation. X-ray absorption measurements indicated a distinct nanocubane structure, where $13 \mathrm{Co}$ atoms were fully coordinated with $\mathrm{O}$ atom by a six-coordinate pattern to form $8 \mathrm{Co}_{4} \mathrm{O}_{4}$ cubanes, which may explain the unusually robust water oxidation catalytic activity. So, a smaller particle size and $\mathrm{Co}^{3+}$ produce better catalytic activity.

Here, the valence of $\mathrm{Cu}$ in the $\mathrm{CuO}$ microspheres and commercial $\mathrm{CuO}$ was +2 by the XPS analysis. The $\mathrm{CuO}$ microspheres $\left(A_{\mathrm{BET}}=15 \mathrm{~m}^{2} / \mathrm{g}\right)$ gave a superior catalytic activity $(\mathrm{TOF}=$ $2.5 \times 10^{-4} \mathrm{~s}^{-1}$ per $\left.\mathrm{Cu}\right)$ to that of commercial $\mathrm{CuO}\left(A_{\mathrm{BET}}=3 \mathrm{~m}^{2} / \mathrm{g}\right.$, TOF $=0.4 \times 10^{-4} \mathrm{~s}^{-1}$ per $\mathrm{Cu}$ ) for photochemical water oxidation. The results suggested that the photocatalytic activity of $\mathrm{CuO}$ depended mainly on the surface area of the catalyst.

\subsection{Stability study}

A fresh buffer solution containing $\left[\mathrm{Ru}(\mathrm{bpy})_{3}\right] \mathrm{Cl}_{2} \quad(1.0$ $\mathrm{mmol} / \mathrm{L})$ and $\mathrm{Na}_{2} \mathrm{~S}_{2} \mathrm{O}_{8}(5.0 \mathrm{mmol} / \mathrm{L})$ was added to the recovered particles for the repetitive examination under photoirradiation. The high catalytic activity of $\mathrm{CuO}$ microspheres was maintained even after the fifth run (Fig. 7). To further check the stability of the $\mathrm{CuO}$ catalyst, XRD (Fig. S17), FT-IR (Fig. S18), TEM (Fig. S19) and Raman (Fig. S20) measurements were performed after the photocatalytic water oxidation. Fig. S17 shows the diffraction peaks of the $\mathrm{CuO}$ after reaction. The typical $\mathrm{CuO}$ diffraction peaks remained and were the same as those before the photocatalytic water oxidation. In addition, FT-IR spectra were used to investigate the surface properties of the $\mathrm{CuO}$. As shown in Fig. S18, there are three peaks observed at $\sim 450,512$ and $592 \mathrm{~cm}^{-1}$, which are the characteristic stretching vibrations of $\mathrm{Cu}-\mathrm{O}$ bond in monoclinic $\mathrm{CuO}$. None of the peaks showed a change after the photocatalytic water oxidation. No variation in the morphology of the $\mathrm{CuO}$ microsphere catalyst was observed (Fig. S19) before and after the reaction. In addition, a catalytic test of the supernatant solution was performed. No $\mathrm{O}_{2}$ was de-

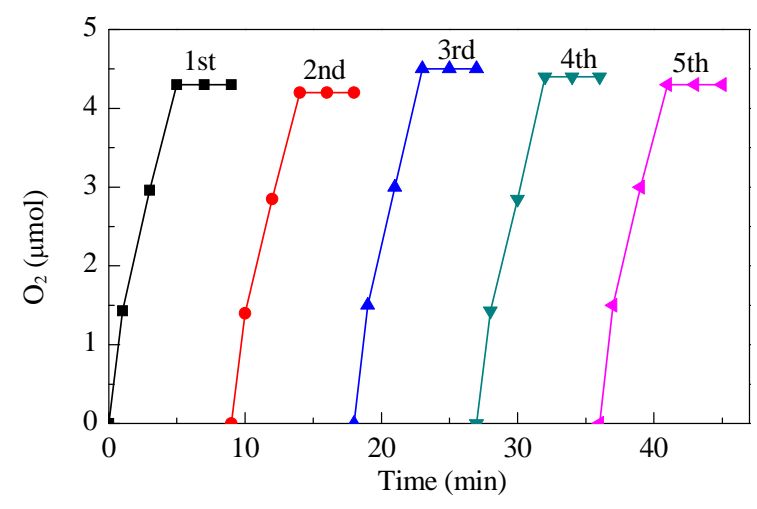

Fig. 7. Kinetics of $\mathrm{O}_{2}$ formation in the photocatalytic system using fresh $\mathrm{CuO}$ microspheres and recovered $\mathrm{CuO}$ microspheres. Other conditions were the same as in Fig. 4 (pH 8.5, 80 mmol/L NaBi).

tected after the catalytic tests by the addition of $\left[\mathrm{Ru}(\mathrm{bpy})_{3}\right] \mathrm{Cl}_{2}$ and $\mathrm{Na}_{2} \mathrm{~S}_{2} \mathrm{O}_{8}$ to the supernatant solution, which excluded $\mathrm{Cu}^{2+}$ leaching as a source of smaller secondary (amorphous) nano-catalysts. However, particle was detected when $\mathrm{Cu}\left(\mathrm{NO}_{3}\right)_{2}$. $3 \mathrm{H}_{2} \mathrm{O}$ was used as photocatalytic water oxidation catalyst (Fig. S21). These results clearly indicated that the $\mathrm{CuO}$ microspheres a highly active and robust catalyst in the photocatalytic system. Our earlier work [38] revealed that the surface of the catalyst after the photochemical measurements could show micro-phase separation and deactivation of the catalyst. A series of characterization were performed based on this knowledge. We carried out XPS measurements after the reaction to understand this surface phenomenon. XPS was performed to check the valence states and surface properties of the $\mathrm{CuO}$ sample after the photocatalytic reaction. Fig. 8(a) and (b) shows the high resolution XPS spectra of $\mathrm{Cu} 2 p$ and $01 s$ before and after reaction. The binding energy of each element was calibrated by the $\mathrm{C} 1 s$ peak (284.8 eV). Fig. 8(a) shows the XPS spectra for $\mathrm{Cu}$ $2 p_{3 / 2}$ peaks at $933.7 \mathrm{eV}$ with two satellite peaks at 941.0 and $943.5 \mathrm{eV}$ and $\mathrm{Cu} 2 p_{1 / 2}$ peaks at $953.7 \mathrm{eV}$ with a satellite peak at $962.5 \mathrm{eV}$ for the $\mathrm{CuO}$ microspheres samples before and after the reaction. The binding energies of these peaks indicated the $\mathrm{Cu}$ species in the sample was $\mathrm{Cu}^{2+}$ by comparison with the peak positions of the $\mathrm{Cu} 2 p$ peaks of $\mathrm{CuO}$ [51]. Fig. 8(b) exhibits that the XPS spectrum had the $01 s$ peak at $529.6 \mathrm{eV}$ with another peak at $531.4 \mathrm{eV}$ for the $\mathrm{CuO}$ microspheres before the reaction and the peaks were at $529.7 \mathrm{eV}$ with another peak at $531.4 \mathrm{eV}$ after the reaction. Although the main $01 s$ peak from the sample after the reaction was slightly shifted to higher binding energy, the same separation between the main peak and satellite peak in both samples and the similarity of peak shapes including the satellite peaks in the whole energy region between 528 and $536 \mathrm{eV}$ strongly suggested that there was no change in the valence state of $\mathrm{O}^{2-}$. Therefore, the XRD, FT-IR, and XPS results indicated that the $\mathrm{CuO}$ material was a highly robust catalyst in the photocatalytic water oxidation.

\subsection{Mechanism study}

In a recent mechanistic study, water oxidation intermediates were observed using a time-resolved FT-IR technique. Frei 

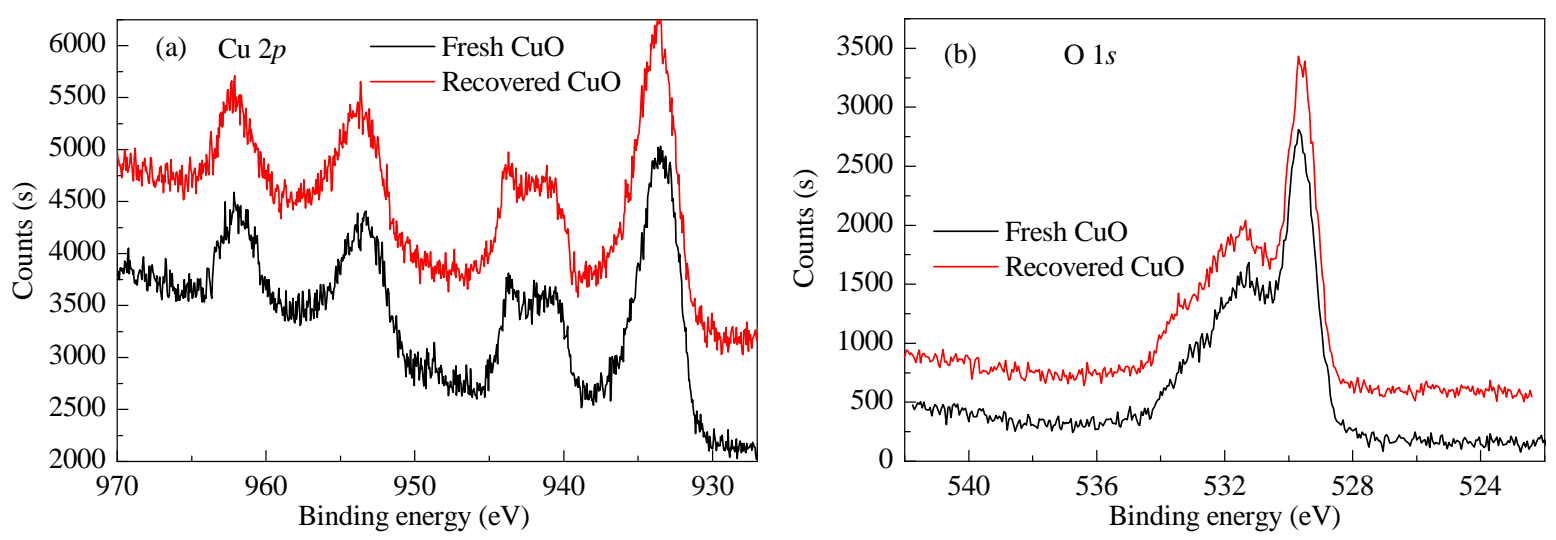

Fig. 8. XPS of $\mathrm{CuO}$ microspheres before and after the reaction in the energy regions of $\mathrm{Cu} 2 p(\mathrm{a})$ and $\mathrm{O} 1 s$ (b) of $\mathrm{CuO}$ microspheres before and after the reaction.

and co-workers [52] studied the behaviour of $\mathrm{Co}_{3} \mathrm{O}_{4}$ nano-particles in the visible light driven $\left[\mathrm{Ru}(\mathrm{bpy})_{3}\right]^{2+}-\mathrm{S}_{2} \mathrm{O}_{8}{ }^{2-}$ system and proposed two distinct active sites, namely oxo-bridged Co(III)OH binuclear site and single Co(III)OH sites. The time-resolved FT-IR measurements demonstrated that the presence of adjacent $\mathrm{CoOH}$ groups accompanied an oxygen bridge led to an active site with a TOF higher than $3 \mathrm{~s}^{-1}$, while the single cobalt site exhibited a much slower TOF $\left(\sim 0.02 \mathrm{~s}^{-1}\right.$ per surface atom). $\mathrm{Cu}^{\mathrm{II}}$ has both suitable redox properties and coordination pattern based on the oxidation to $\mathrm{Cu}^{\text {III }}$ or even $\mathrm{Cu}^{\mathrm{IV}}$ and reduction to $\mathrm{Cu}^{0}$ or $\mathrm{Cu}^{\mathrm{I}}$ [53-56]. With a propensity for square planar coordination, $\mathrm{d}^{8} \mathrm{Cu}^{\mathrm{III}}$ is active in reactions of copper compounds containing organic ligands and in bis(m-oxo)-bridged complexes. $\mathrm{Cu}^{\mathrm{IV}}$ complexes stabilized either by fluoride ligands or as linear $\mathrm{O}=\mathrm{Cu}=\mathrm{O}$ are also known. Copper complexes of a high oxidation state have been shown to oxidize phenols [54], alcohols [55] and even hydrocarbons [53]. In our $\mathrm{CuO}$ microsphere photocatalytic water oxidation system, a TOF of $2.5 \times 10^{-4}\left(\mathrm{~s}^{-1}\right.$ per $\left.\mathrm{Cu}\right)$ was observed under optimal condition. This can be related to the special property of $\mathrm{CuO}$ because it can undergo a change of the oxidation state in the oxygen evolution reaction (OER) that is similar to cobalt oxide [57]. Therefore, we suggest that regardless of the presence of $\mathrm{Cu}-\mathrm{O}-\mathrm{Cu}$, the dominant reaction pathway for the copper oxide catalyst is the single $\mathrm{Cu}(\mathrm{II}) \mathrm{OH}$ site mechanism.

There are several reasons why a significantly high $\mathrm{O}_{2}$ yield has not been obtained yet. For example, electron injection from an adjacent $\mathrm{Cu}(\mathrm{II}) \mathrm{OH}$ site to the $\left[\mathrm{Ru}(\mathrm{bpy})_{3}\right]^{2+}$ sensitizer can be difficult due to the short $\mathrm{Cu}-0$ distance (1.95 or $1.96 \AA$ ) compared to the $\left[\mathrm{Ru}(\mathrm{bpy})_{3}\right]^{2+}$ complex $(11 \AA)$ ). In addition, electron transfer from the $\mathrm{Cu}(\mathrm{II}) \mathrm{OH}$ active site to the $\left[\mathrm{Ru}(\mathrm{bpy})_{3}\right]^{2+}$ sensitizer is a random process with no control of the direction, which also reduce the synergism of two adjacent $\mathrm{Cu}$ atoms. A precise control of electron transfer has to be optimized to achieve a high $\mathrm{O}_{2}$ yield. Third, the catalytic potential of the $\mathrm{CuO}$ microspheres was only $0.13 \mathrm{~V}$ lower than that of $\left[\mathrm{Ru}(\mathrm{bpy})_{3}\right]^{2+}$, which indicated that $\left[\mathrm{Ru}(\mathrm{bpy})_{3}\right]^{3+}$ only weakly drive the $\mathrm{CuO}$ microspheres to oxidize water. Further investigation will be carrying out to fully determine the water oxidation reaction mechanism on the surface of $\mathrm{CuO}$ microspheres.

\section{Conclusions}

This is the first report where a copper species was demonstrated to be a photocatalytic water oxidation catalyst under near neutral conditions. The $\mathrm{CuO}$ catalyst exhibited excellent water oxidation activity and stability. No change was found by XPS analysis in the surface condition of the $\mathrm{CuO}$ microspheres before and after the photocatalytic reaction. Copper is an attractive material because of its abundance and lower price than other elements such as $\mathrm{Co}, \mathrm{Ni}$, and Mo. A photocatalytic water oxidation reaction mechanism catalyzed by the $\mathrm{CuO}$ microspheres was proposed. Easy preparation, low toxicity, and rich redox properties render the $\mathrm{Cu}$-based photocatalyst favorable for future water splitting applications.

\section{References}

[1] N. S. Lewis, D. G. Nocera, Proc. Natl. Acad. Sci. USA, 2006, 103, 15729-15735.

[2] X. Q. Du, J. L. Zhao, J. Q. Mi, Y. Ding, P. P. Zhou, B. C. Ma, J. W. Zhao, J. Song, Nano Energy, 2015, 16, 247-255.

[3] F. Y. Wen, C. Li, Acc. Chem. Res., 2013, 46, 2355-2364.

[4] D. J. Martin, G. G. Liu, S. J. A. Moniz, Y. P. Bi, A. M. Beale, J. H. Ye, J. W. Tang, Chem. Soc. Rev., 2015, 44, 7808-7828.

[5] D. J. Martin, P. J. T. Reardon, S. J. A. Moniz, J. W. Tang, J. Am. Chem. Soc., 2014, 136, 12568-12571.

[6] C. W. Cady, R. H. Crabtree, G. W. Brudvig, Coord. Chem. Rev., 2008, $252,444-455$.

[7] Z. Liu, Y. Gao, Z. Yu, M. Zhang, J. H. Liu, Chin. J. Catal., 2015, 36, 1742-1749.

[8] Y. Jiang, F. Li, F. Huang, B. B. Zhang, L. C. Sun, Chin. J. Catal., 2013, 34, 1489-1495.

[9] X. B. Han, Z. M. Zhang, T. Zhang, Y. G. Li, W. B. Lin, W. S. You, Z. M. Su, E. B. Wang, J. Am. Chem. Soc., 2014, 136, 5359-5366.

[10] D. Hong, J. Jung, J. Park, Y. Yamada, T. Suenobu, Y. M. Lee, W. Nam, S. Fukuzumi, Energy Environ. Sci., 2012, 5, 7606-7616.

[11] Z. Q. Huang, Z. Luo, Y. V. Geletii, J. W. Vickers, Q. S. Yin, D. Wu, Y. Hou, Y. Ding, J. Song, D. G. Musaev, C. L. Hill, T. Q. Lian, J. Am. Chem. Soc., 2011, 133, 2068-2071.

[12] F. Y. Song, Y. Ding, B. C. Ma, C. M. Wang, Q. Wang, X. Q. Du, S. Fu, J. Song, Energy Environ. Sci., 2013, 6, 1170-1184.

[13] R. Xiang, Y. Ding, J. W. Zhao, Chem. Asian J., 2014, 9, 3228-3273. 


\section{Graphical Abstract}

Chin. J. Catal., 2016, 37: 123-134 doi: 10.1016/S1872-2067(15)61012-9

Flower-like 3D CuO microsphere acting as photocatalytic water oxidation catalyst

Xiaoqiang Du, Jingwei Huang, Yingying Feng, Yong Ding * Lanzhou University;

Lanzhou Institute of Chemical Physics, Chinese Academy of Sciences

A flower-like 3D CuO microspheres based on earth abundant elements has been successfully synthesized. It is the first time that a copper oxide shows efficient photocatalytic water oxidation performance with good stability.

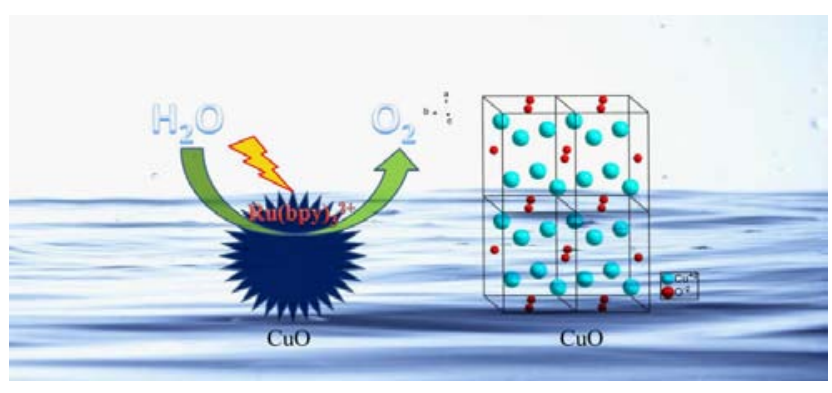

[14] H. J. Lv, Y. V. Geletii, C. C. Zhao, J. W. Vickers, G. B. Zhu, Z. Luo, J. Song, T. Q. Lian, D. G. Musaev, C. L. Hill, Chem. Soc. Rev., 2012, 41, 7572-7589.

[15] S. Fu, Y. D. Liu, Y. Ding, X. Q. Du, F. Y. Song, R. Xiang, B. C. Ma, Chem. Commun., 2014, 50, 2167-2169.

[16] F. Evangelisti, R. Guttinger, R. More, S. Luber, G. R. Patzke, J. Am. Chem. Soc., 2013, 135, 18734-18737.

[17] C. F. Leung, S. M. Ng, C. C. Ko, W. L. Man, J. S. Wu, L. J. Chen, T. C. Lau, Energy Environ. Sci., 2012, 5, 7903-7907.

[18] Y. K. Zhao, Y. D. Liu, X. Q. Du, R. X. Han, Y. Ding, J. Mater. Chem. A, 2014, 2, 19308-19314.

[19] Y. Yamada, K. Yano, D. C. Hong, S. Fukuzumi, Phys. Chem. Chem. Phys., 2012, 14, 5753-5760.

[20] F. Jiao, H. Frei, Angew. Chem. Int. Ed., 2009, 48, 1841-1844.

[21] A. Indra, P. W. Menezes, N. R. Sahraie, A. Bergmann, C. Das, M. Tallarida, D. Schmeisser, P. Strasser, M. Driess, J. Am. Chem. Soc., 2014, 136, 17530-17536.

[22] G. S. Hutchings, Y. Zhang, J. Li, B. T. Yonemoto, X. G. Zhou, K. K. Zhu, F. Jiao, J. Am. Chem. Soc., 2015, 137, 4223-4229.

[23] J. Zhao, Y. C. Zou, X. X. Zou, T. Y. Bai, Y. P. Liu, R. Q. Gao, D. J. Wang, G. D. Li, Nanoscale, 2014, 6, 7255-7262.

[24] A. M. Ullman, Y. Liu, M. Huynh, D. K. Bediako, H. Wang, B. L. Anderson, D. C. Powers, J. J. Breen, H. D. Abruna, D. G. Nocera, J. Am. Chem. Soc., 2014, 136, 17681-17688.

[25] F. Jiao, H. Frei, Energy Environ. Sci., 2010, 3, 1018-1027.

[26] J. Wei, Y. Liu, Y. Ding, C. Luo, X. Q. Du, J. Q. Lin, Chem. Commun., 2014, 50, 11938-11941.

[27] R. Al-Oweini, A. Sartorel, B. S. Bassil, M. Natali, S. Berardi, F. Scandola, U. Kortz, M. Bonchio, Angew. Chem. Int. Ed., 2014, 53, 11182-11185.

[28] G. C. Dismukes, R. Brimblecombe, G. A. N. Felton, R. S. Pryadun, J. E. Sheats, L. Spiccia, G. F. Swiegers, Acc. Chem. Res., 2009, 42, 1935-1943.

[29] W. C. Ellis, N. D. McDaniel, S. Bernhard, T. J. Collins, J. Am. Chem. Soc., 2010, 132, 10990-10991.

[30] J. L. Fillol, Z. Codolà, I. Garcia Bosch, L. Gómez, J. J. Pla, M. Costas, Nat. Chem., 2011, 3, 807-813.

[31] X. Q. Du, Y. Ding, F. Y. Song, B. C. Ma, J. L. Zhao, J. Song, Chem. Commun., 2015, 51, 13925-13928.

[32] G. Chen, L. J. Chen, S. L. Ng, W. M. Man, T. C. Lau, Angew. Chem. Int. Ed., 2013, 52, 1789-1791.

[33] S. M. Barnett, K. I. Goldberg, J. M. Mayer, Nat. Chem., 2012, 4, 498-502.

[34] J. E. Yourey, K. J. Pyper, J. B. Kurtz, B. M. Bartlett, J. Phys. Chem. C, 2013, 117, 8708-8718.
[35] Z. F. Chen, T. J. Meyer, Angew. Chem. Int. Ed., 2013, 52, 700-703.

[36] F. S. Yu, F. Li, B. B. Zhang, H. Li, L. C. Sun, ACS Catal., 2015, 5, 627-630.

[37] T. Zhang, C. Wang, S. B. Liu, J. L. Wang, W. B. Lin, J. Am. Chem. Soc., 2014, 136, 273-281.

[38] X. Du, Y. Ding, R. Xiang, X. Xiang, Phys. Chem. Chem. Phys., 2015, 17, 10648-10655.

[39] M. P. Santoni, G. La Ganga, V. Mollica Nardo, M. Natali, F. Puntoriero, F. Scandola, S. Campagna, J. Am. Chem. Soc., 2014, 136, 8189-8192.

[40] X. Q. Du, J. Wei, J. L. Zhao, R. X. Han, Y. Ding, Chem. Asian J., 2014, 9, 2745-2750.

[41] G. Chen, L. J. Chen, S. M. Ng, T. C. Lau, ChemSusChem, 2014, 7, 127-134.

[42] D. C. Hong, Y. Yamada, T. Nagatomi, Y. Takai, S. Fukuzumi, J. Am. Chem. Soc., 2012, 134, 19572-19575.

[43] M. Zhang, M. T. Zhang, C. Hou, Z. F. Ke, T. B. Lu, Angew. Chem. Int. Ed., 2014, 53, 13042-13048.

[44] G. B. Zhu, E. N. Glass, C. C. Zhao, H. J. Lv, J. W. Vickers, Y. V. Geletii, D. G. Musaev, J. Song, C. L. Hill, Dalton Trans., 2012, 41, 1304313049.

[45] X. B. Han, Y. G. Li, Z. M. Zhang, H. Q. Tan, Y. Lu, E. B. Wang, J. Am. Chem. Soc., 2015, 137, 5486-5493.

[46] W. H. He, Y. Yang, L. Wang, J. J. Yang, X. Xiang, D. P. Yan, F. Li, ChemSusChem, 2015, 8, 1568-1576.

[47] Z. F. Chen, T. J. Meyer, Angew. Chem. Int. Ed., 2013, 52, 700-703.

[48] S. F. Zheng, J. S. Hu, L. S. Zhong, W. G. Song, L. J. Wan, Y. G. Guo, Chem. Mater., 2008, 20, 3617-3622.

[49] C. Creutz, N. Sutin, Proc. Natl. Acad. Sci. USA, 1975, 72, 2858-2862.

[50] P. K. Ghosh, B. S. Brunschwig, M. Chou, C. Creutz, N. Sutin, J. Am. Chem. Soc., 1984, 106, 4772-4783.

[51] L. Kundakovic, M. Flytzani Stephanopoulos, Appl. Catal. A, 1998, 171, 13-29.

[52] M. Zhang, M. de Respinis, H. Frei, Nat. Chem., 2014, 6, 362-367.

[53] M. Taki, S. Itoh, S. Fukuzumi, J. Am. Chem. Soc., 2001, 123, 6203-6204.

[54] S. Mahapatra, S. Kaderli, A. Llobet, Y. M. Neuhold, T. Palanche, J. A. Halfen, V. G. Young, T. A. Kaden, L. Que, A. D. Zuberbuhler, W. B. Tolman, Inorg. Chem., 1997, 36, 6343-6356.

[55] P. Kang, E. Bobyr, J. Dustman, K. O. Hodgson, B. Hedman, E. I. Solomon, T. D. Stack, Inorg. Chem., 2010, 49, 11030-11038.

[56] L. M. Mirica, X. Ottenwaelder, T. D. P. Stack, Chem. Rev., 2004, 104, 1013-1046.

[57] K. Kwapien, S. Piccinin, S. Fabris, J. Phys. Chem. Lett., 2013, 4, 4223-4230. 


\title{
花状的三维 CuO微球作为光催化水氧化催化剂
}

\author{
杜晓强 ${ }^{\mathrm{a}}$, 黄静伟 ${ }^{\mathrm{a}}$ ，丰营营 ${ }^{\mathrm{a}}$,丁 勇, ${ }^{\mathrm{a}, \mathrm{b}, *}$ \\ a 兰州大学化学化工学院, 甘肃省有色金属重点实验室, 功能有机分子国家重点实验室, 甘肃兰州730000 \\ b 中国科学院兰州化学物理研究所, 羰基合成与选择氧化国家重点实验室, 甘肃兰州730000
}

摘要: 由于化石燃料的不可持续性, 以及燃烧化石燃料释放的大量 $\mathrm{CO}_{2}$ 产生的温室效应、环境污染等严重的全球性问题, 构 建洁净的、环境友好的、非化石燃料的可再生新能源体系成为世界各国高度关注的焦点和重大战略部署. 在化石燃料日 趋减少的情况下, 太阳能已成为人类使用能源的重要组成部分, 并不断得到发展. 从实用性角度出发, 利用人工光合作用 直接将光能转化为化学能吸引了国内外许多研究小组的兴趣. 太阳能裂解水制氢是解决能源危机的最理想途径之一. 然 而, 水的氧化涉及到4电子和4质子的转移过程, 是能量爬坡的艰难过程. 所以, 水的氧化是制约水裂解的一个瓶颈.

寻找高效、稳定、廉价的水氧化催化剂成为水裂解的重中之重. 然而, 廉价、制备方法简单、效率高、容易回收的水 氧化催化剂仍不多. 已有文献报道了一些含 $\mathrm{Co}, \mathrm{Fe}, \mathrm{Mn}$ 和 Ni的光催化水氧化催化剂. 值的一提的是, $\mathrm{Cu}$ 作为地球上第八位 丰产元素, 由于它合适的氧化还原性质和可调控的配位环境, 理论上应该是一个高效的水氧化催化剂. 然而, Cu很少被用 作水氧化催化剂. 2012年, Mayer等报道了第一例含铜的均相电催化水氧化催化剂. 2013年, Meyer等报道了非常高效和稳 定的简单 $\mathrm{Cu}^{\mathrm{II}}$ 盐电催化水氧化催化剂. 2014年, Lin等报道了一个碱性的水溶液中混合 $\mathrm{Cu}(\mathrm{II})$ 盐和6,6-dihydroxy-2,2-bipyri-

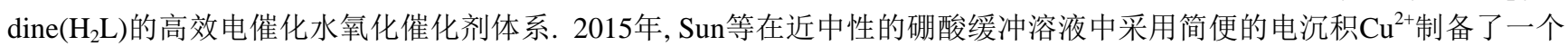
高效的铜氧化物电催化水氧化催化剂. 然而, 基于地球上充足的Cu设计高效、容易制备和稳定的光催化水氧化催化剂, 仍 是一个巨大的挑战.

本文基于地球丰产元素 $\mathrm{Cu}$ 和 $\mathrm{O}$, 成功合成了花状的三维 $\mathrm{CuO}$ 微球, 并采用扫描电镜、透射电镜、红外光谱、 $\mathrm{X}$ 射线粉末 衍射、拉曼光谱、 $\mathrm{X}$ 射线光电子能谱、 $\mathrm{N}_{2}$ 吸附脱附等温线对 $\mathrm{CuO}$ 样品的物相、元素组成、颗粒大小以及比表面积等进行了 表征. 在可见光下, 以 $\left[\mathrm{Ru}(\mathrm{bpy})_{3}\right]^{2+}$ 为光敏剂, $\mathrm{Na}_{2} \mathrm{~S}_{2} \mathrm{O}_{8}$ 为牺牲电子受体, 首次报道了 $\mathrm{CuO}$ 微球用作水氧化催化剂. 通过一系 列控制实验证明 $\mathrm{CuO}$ 确实参与了催化过程. 据我们所知, 这是第一例铜物种在近中性条件下被证明具有光催化水氧化催化 性能. 通过对缓冲溶液、 $\mathrm{pH}$ 值和催化剂浓度的优化, 在硼酸缓冲溶液 $(\mathrm{pH}=8.5)$ 中产生的 $\mathrm{O}_{2}$ 收率为 $11.5 \%, \mathrm{CuO}$ 显示了最佳的 催化活性. 进一步研究表明, $\mathrm{CuO}$ 表现出卓越的水氧化催化性能和稳定性. 催化剂重复使用 5 次后活性基本保持不变. 反应 前后的催化剂组成和形貌基本没有发生改变, 其表面性质也未发生明显变化. ${ }^{18} \mathrm{O}$ 标记的重氧水实验证明, 氧气中的氧确实 是来自于水. 实验发现, 催化剂活性主要取决于其比表面积. 结合已报道的文献, 我们初步提出了一个光催化水氧化反应 机理. 相对于钴、镍和钒, 铜丰度高, 价格更低, 具有更好的发展潜力. 可见, 丰度高、低毒性和合适的氧化还原性质使铜催 化剂填补了光催化水分解的一项空白.

关键词: 光催化; 水氧化; 金属催化剂; 氧化铜微球; 稳定性

收稿日期: 2015-10-29. 接受日期: 2015-11-07. 出版日期: 2016-01-05.

*通讯联系人. 电话: (0931)8912585; 电子信箱: dingyong1@lzu.edu.cn

基金来源：国家自然科学基金(21173105, 21172098).

本文的英文电子版由Elsevier出版社在ScienceDirect上出版(http://www.sciencedirect.com/science/journal/18722067).

\section{Supporting Information}

\section{Table S1}

Water oxidation catalyzed without $\mathrm{CuO}$ or $\mathrm{Ru}(\mathrm{bpy})_{3} \mathrm{Cl}_{2}$ or persulfate or light.

\begin{tabular}{lccccc}
\hline Entry & $\begin{array}{c}{\left[\mathrm{Ru}(\mathrm{bpy})_{3}\right] \mathrm{Cl}_{2}} \\
(\mathrm{mmol} / \mathrm{L})\end{array}$ & $\begin{array}{c}\mathrm{Na}_{2} \mathrm{~S}_{2} \mathrm{O}_{8} \\
(\mathrm{mmol} / \mathrm{L})\end{array}$ & $\begin{array}{c}\text { Catalyst } \\
(\mathrm{g} / \mathrm{L})\end{array}$ & light & $\mathrm{O}_{2}(\mu \mathrm{mol})$ \\
\hline 1 & 1 & 5 & 0 & yes & 0.5 \\
2 & 1 & 0 & 0.5 & yes & 0 \\
3 & 0 & 5 & 0.5 & yes & 0 \\
4 & 1 & 5 & 0.5 & no & 0 \\
\hline
\end{tabular}

Conditions: LED lamp $(\lambda \geq 420 \mathrm{~nm})$, sodium borate buffer (initial $\mathrm{pH} 8.5$. $80 \mathrm{mmol} / \mathrm{L}$, total reaction volume $15 \mathrm{~mL}$, overall volume $\sim 28 \mathrm{~mL}$, vigorous agitation using a magnetic stirrer.

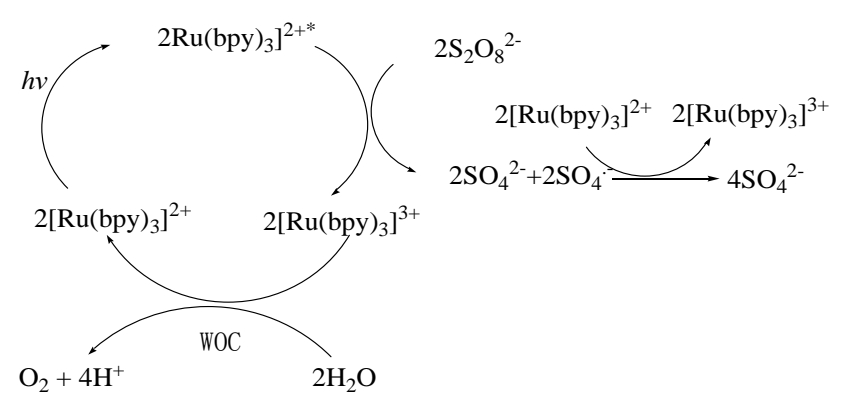

Scheme S1. Process of $\mathrm{O}_{2}$ evolution in a light-driven water oxidation system. 


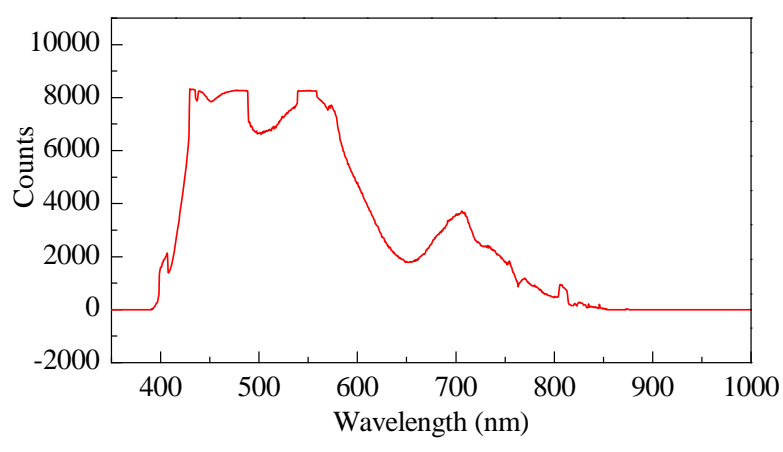

Fig. S1. Spectrum of the LED lamp.

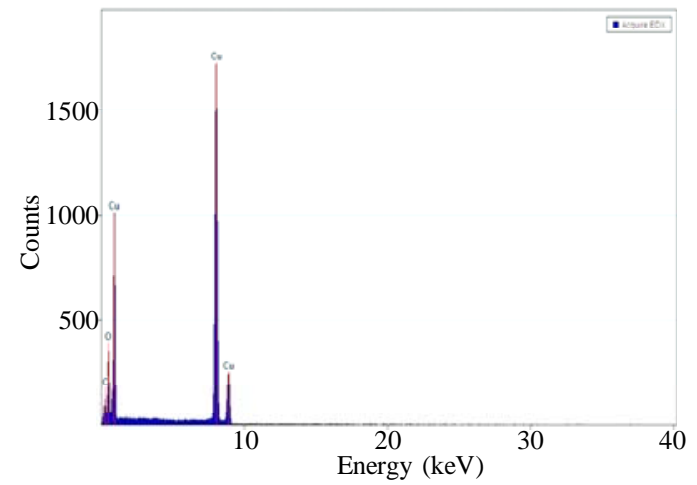

Fig. S2. EDS of the $\mathrm{CuO}$ microspheres.

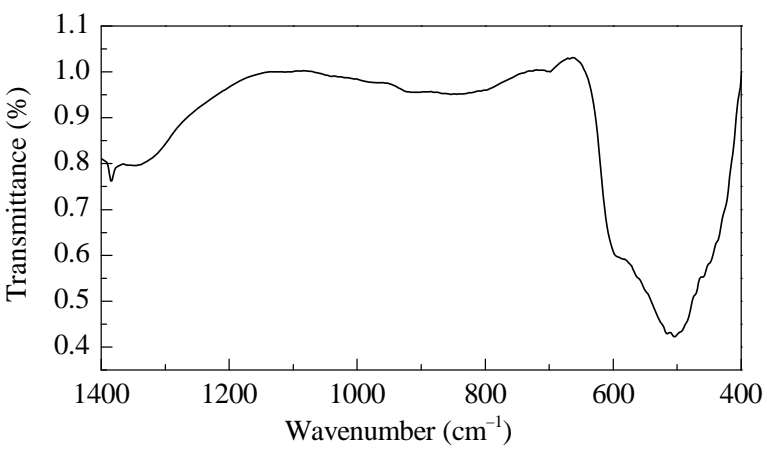

Fig. S3. FT-IR spectrum of the products of the $\mathrm{CuO}$ microspheres. There were three infrared peaks observed at $\sim 450,512$ and $592 \mathrm{~cm}^{-1}$, which are the characteristic stretching vibrations of $\mathrm{Cu}-\mathrm{O}$ bond in monoclinic $\mathrm{CuO}$. The high-frequency mode at $\sim 592 \mathrm{~cm}^{-1}$ may be a $\mathrm{Cu}-\mathrm{O}$ stretching along the [-101] direction, and the mode ate $\sim 512 \mathrm{~cm}^{-1}$ may be $\mathrm{Cu}-0$ stretching along the [101]. These data are same as reported data.

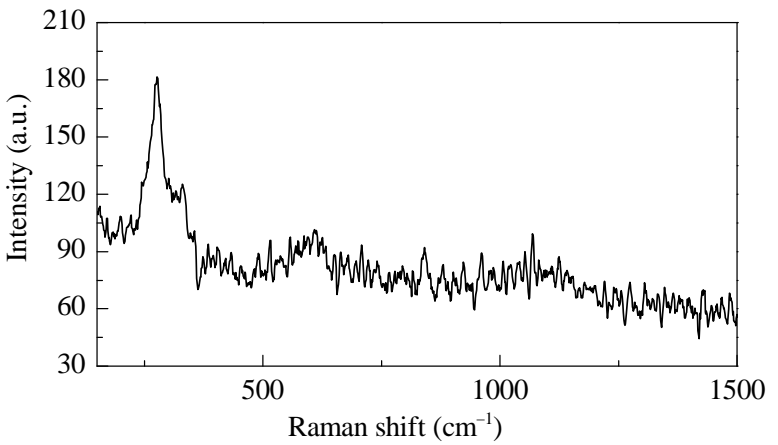

Fig. S4. Raman spectrum of $\mathrm{CuO}$ microspheres excited by $514.5 \mathrm{~nm}$ laser.
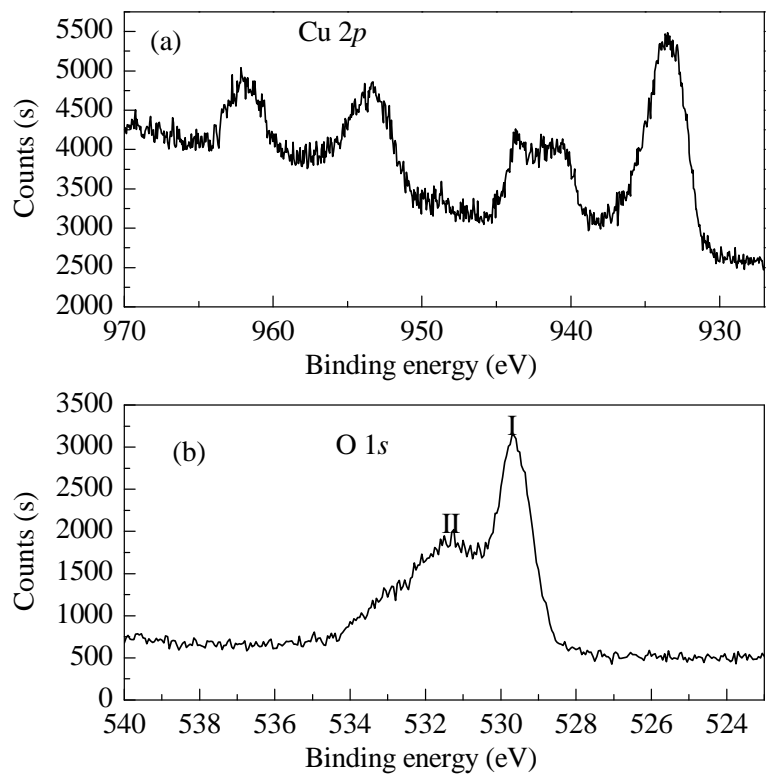

Fig. S5. XPS spectra of $\mathrm{CuO}$ microspheres. (a) $\mathrm{Cu} 2 p$; (b) $01 s$.

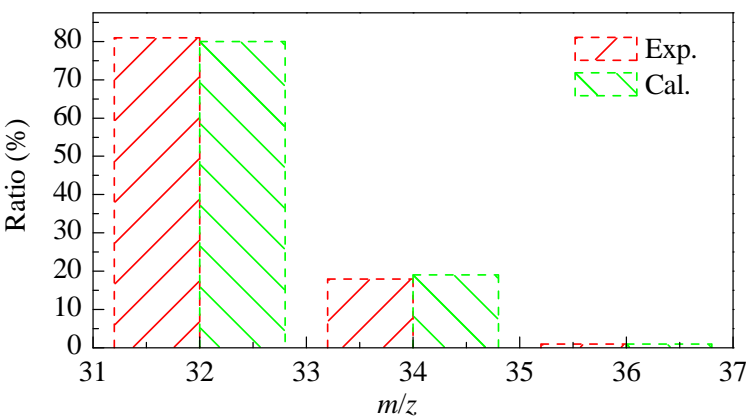

Fig. S6. Observed and theoretical relative abundances of ${ }^{18} 0$-labeled and unlabeled oxygen evolved during the photocatalytic oxidation of a buffer solution $(4.5 \mathrm{~mL})$ prepared with $\mathrm{H}_{2}{ }^{18} \mathrm{O}$-enriched water $(10.8 \%$ $\left.\mathrm{H}_{2}{ }^{18} \mathrm{O}\right)$ containing $\mathrm{CuO}(0.5 \mathrm{~g} / \mathrm{L}),\left[\mathrm{Ru}(\mathrm{bpy})_{3}\right] \mathrm{Cl}_{2}(1.0 \mathrm{mmol} / \mathrm{L})$ and $\mathrm{Na}_{2} \mathrm{~S}_{2} \mathrm{O}_{8}$ (5.0 mmol/L) Exp.-observed mass intensity; Cal. —calculated values assuming that evolved $\mathrm{O}_{2}$ results exclusively from water.

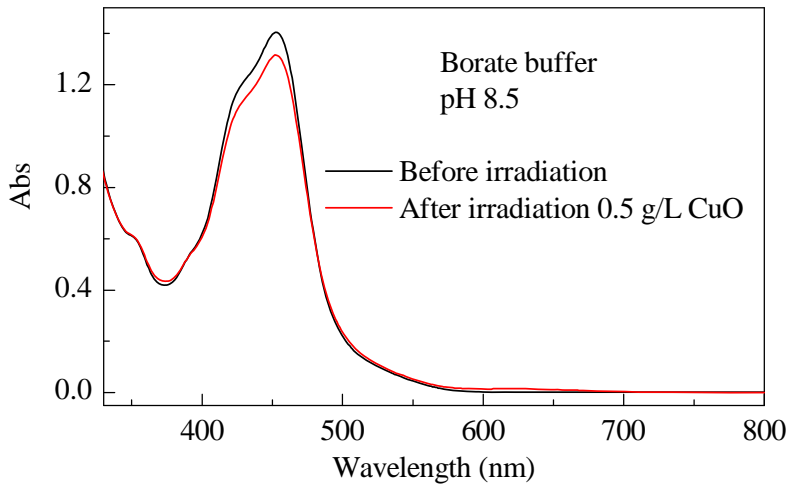

Fig. S7. UV-vis spectral changes during the photocatalytic $\mathrm{O}_{2}$ evolution with $\mathrm{CuO}$ microspheres. The black line shows the absorption of aqueous borate buffer solutions $(\mathrm{pH} 8.5,80 \mathrm{mmol} / \mathrm{L})$ containing $\left[\mathrm{Ru}(\mathrm{bpy})_{3}\right] \mathrm{Cl}_{2}(1.0 \mathrm{mmol} / \mathrm{L}), \mathrm{Na}_{2} \mathrm{~S}_{2} \mathrm{O}_{8}(5.0 \mathrm{mmol} / \mathrm{L})$ and $\mathrm{CuO}$ microspheres $(0.5 \mathrm{~g} / \mathrm{L})$. The red line shows the absorption of above solution after 9 min of irradiation. The concentration of $\left[\mathrm{Ru}(\mathrm{bpy})_{3}\right]^{2+}$ decreased by $6.4 \%$. 


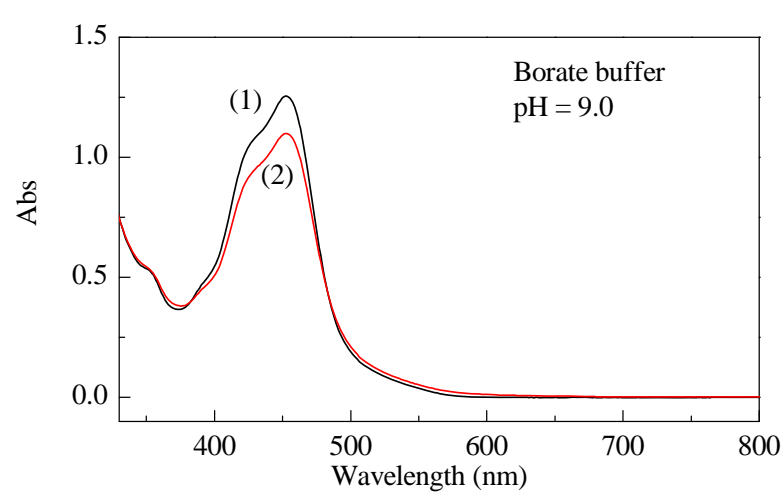

Fig. S8. UV-vis spectral changes during the photocatalytic $\mathrm{O}_{2}$ evolution with $\mathrm{CuO}$ microspheres. (1) Absorption of aqueous borate buffer solu-

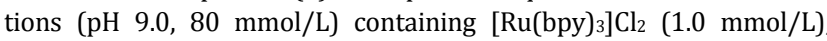
$\mathrm{Na}_{2} \mathrm{~S}_{2} \mathrm{O}_{8}(5.0 \mathrm{mmol} / \mathrm{L})$ and $\mathrm{CuO}$ microspheres $(0.5 \mathrm{~g} / \mathrm{L})$. (2) Absorption by the above solution after $9 \mathrm{~min}$ of irradiation. The concentration of $\left[\mathrm{Ru}(\mathrm{bpy})_{3}\right]^{2+}$ decreased by $12.4 \%$.

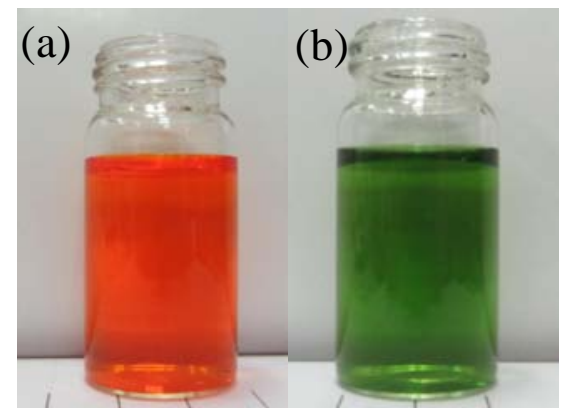

Fig. S9. (a) Solution containing $1.0 \mathrm{mmol} / \mathrm{L}$ of $\left[\mathrm{Ru}(\mathrm{bpy})_{3}\right]^{2+}$ and 5.0 $\mathrm{mmol} / \mathrm{L}$ of $\mathrm{Na}_{2} \mathrm{~S}_{2} \mathrm{O}_{8}$ in $\mathrm{pH}$ 8.0, $80 \mathrm{mmol} / \mathrm{L} \mathrm{NaBi}$ before illumination; (b) Supernatant solution containing $1.0 \mathrm{mmol} / \mathrm{L}$ of $\left[\mathrm{Ru}(\mathrm{bpy})_{3}\right]^{2+}+5.0$ $\mathrm{mmol} / \mathrm{L}$ of $\mathrm{Na}_{2} \mathrm{~S}_{2} \mathrm{O}_{8}+0.5 \mathrm{~g} / \mathrm{L} \mathrm{CuO}$ microspheres in $\mathrm{pH} 8.0,80 \mathrm{mmol} / \mathrm{L}$ $\mathrm{NaBi}$ after illumination for $9 \mathrm{~min}$.

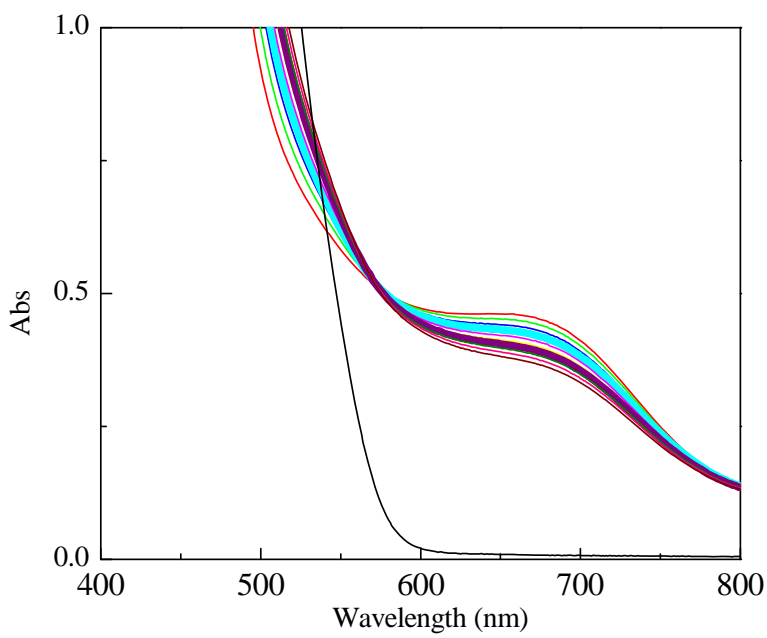

Fig. S10. UV-vis spectral changes during the photocatalytic water oxidation with a $\mathrm{pH} 8.0$ buffer. The bottom green line shows the absorption of an aqueous borate buffer solution ( $\mathrm{pH} 8.0,80 \mathrm{mmol} / \mathrm{L})$ containing $\left[\mathrm{Ru}(\mathrm{bpy})_{3}\right] \mathrm{Cl}_{2}(1.0 \mathrm{mmol} / \mathrm{L}), \mathrm{Na}_{2} \mathrm{~S}_{2} \mathrm{O}_{8}(5.0 \mathrm{mmol} / \mathrm{L})$ and $\mathrm{CuO}$ microspheres $(0.5 \mathrm{~g} / \mathrm{L})$. Other lines show the UV-vis spectral changes of the green reaction solution obtained by irradiating the initial reaction solution about $30 \mathrm{~s}$.

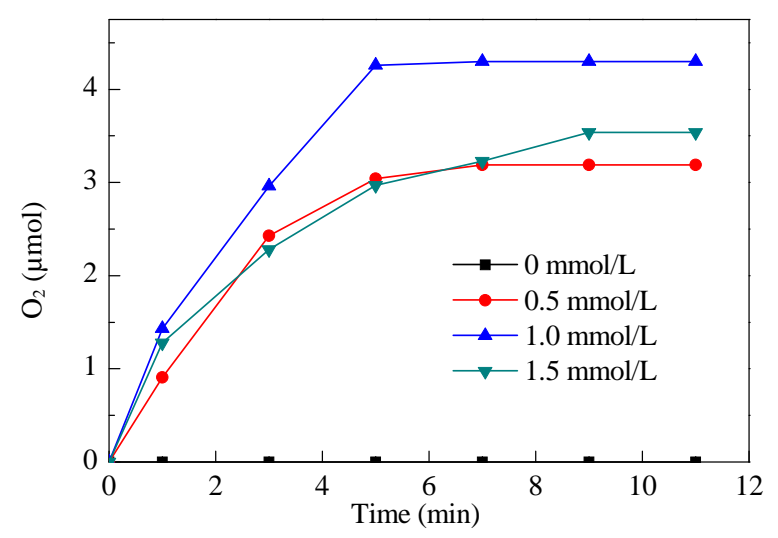

Fig. S11. Kinetics of $\mathrm{O}_{2}$ formation in the photocatalytic system using different concentrations of $\left[\mathrm{Ru}(\mathrm{bpy})_{3}\right] \mathrm{Cl}_{2}$. Conditions: LED lamp $(\lambda \geq$ $420 \mathrm{~nm}$ ), $0.5 \mathrm{~g} / \mathrm{L} \mathrm{CuO} \mathrm{microspheres,} 5.0 \mathrm{mmol} / \mathrm{L} \mathrm{Na}{ }_{2} \mathrm{~S}_{2} \mathrm{O}_{8}, 80 \mathrm{mmol} / \mathrm{L}$ sodium borate buffer (initial $\mathrm{pH} 8.5$ ), total reaction volume $15 \mathrm{~mL}$, overall volume $28 \mathrm{~mL}$, with vigorous agitation using a magnetic stirrer.

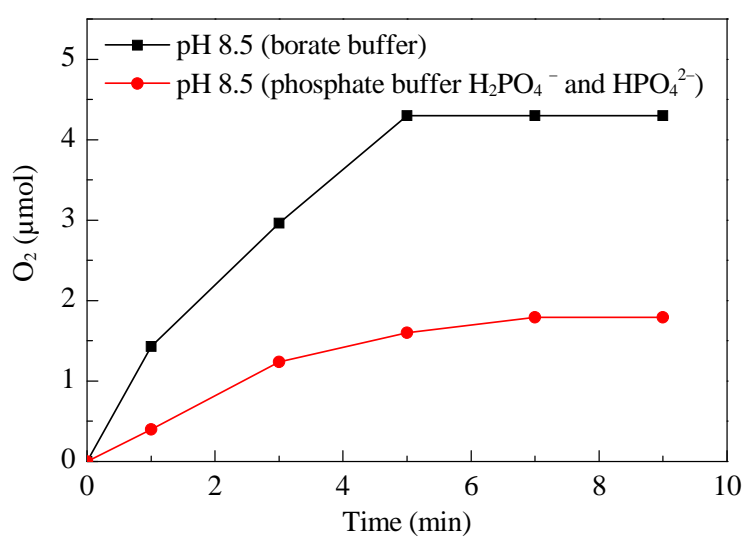

Fig. S12. Kinetics of $\mathrm{O}_{2}$ formation in the photocatalytic system use different kinds of buffers. Conditions: LED lamp $(\lambda \geq 420 \mathrm{~nm})$; catalyst concentration $0.5 \mathrm{~g} / \mathrm{L}, 1.0 \mathrm{mmol} / \mathrm{L}\left[\mathrm{Ru}(\mathrm{bpy})_{3}\right] \mathrm{Cl}_{2}, 5.0 \mathrm{mmol} / \mathrm{L} \mathrm{Na}_{2} \mathrm{~S}_{2} \mathrm{O}_{8}$, $80 \mathrm{mmol} /$ Lsodium borate buffer (initial $\mathrm{pH} \mathrm{8.5);} \mathrm{total} \mathrm{reaction} \mathrm{volume}$ $15 \mathrm{~mL}$, overall volume $28 \mathrm{~mL}$, with vigorous agitation using a magnetic stirrer.

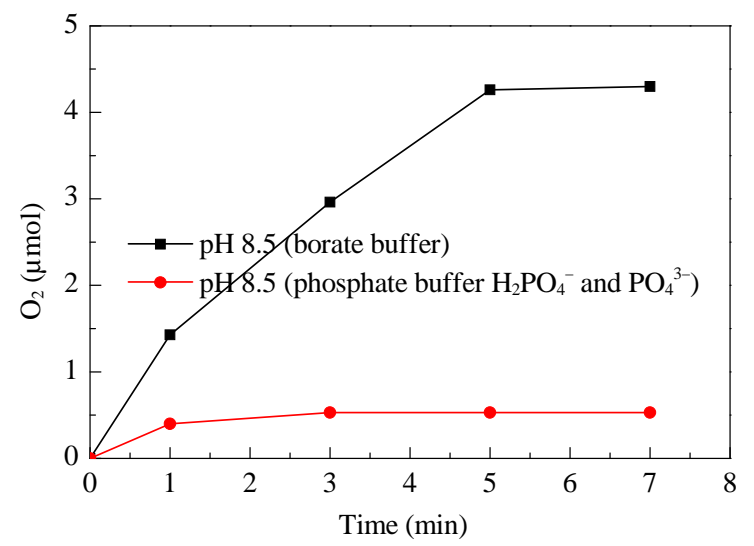

Fig. S13. Kinetics of $\mathrm{O}_{2}$ formation in the photocatalytic system use different kinds of buffers. Conditions: LED lamp $(\lambda \geq 420 \mathrm{~nm})$; catalyst concentration $0.5 \mathrm{~g} / \mathrm{L}, 1.0 \mathrm{mmol} / \mathrm{L}\left[\mathrm{Ru}(\mathrm{bpy})_{3}\right] \mathrm{Cl}_{2}, 5.0 \mathrm{mmol} / \mathrm{L} \mathrm{Na}_{2} \mathrm{~S}_{2} \mathrm{O}_{8}$, total reaction volume $15 \mathrm{~mL}$, overall volume $28 \mathrm{~mL}$, with vigorous agitation using a magnetic stirrer. 


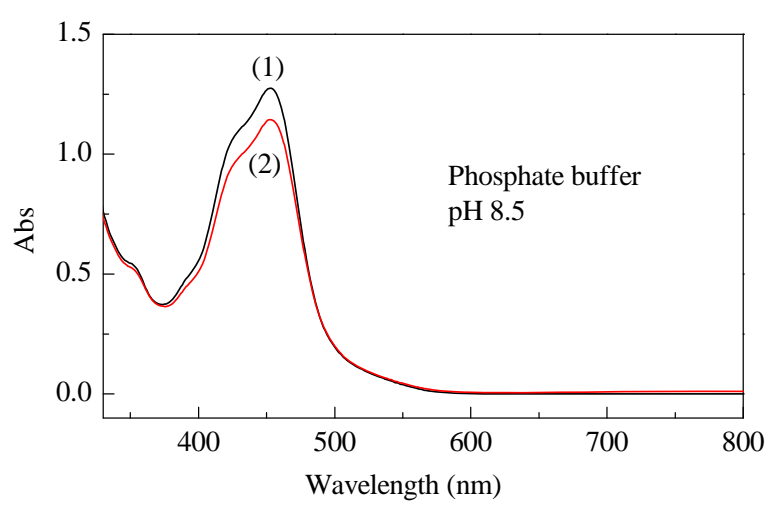

Fig. S14. UV-vis spectral changes during the photocatalytic $\mathrm{O}_{2}$ evolution with $\mathrm{CuO}$ microspheres. (1) Absorption of aqueous phosphate buffer solutions $(\mathrm{pH} 8.5,80 \mathrm{mmol} / \mathrm{L})$ containing $\left[\mathrm{Ru}(\mathrm{bpy})_{3}\right] \mathrm{Cl}_{2}(1.0 \mathrm{mmol} / \mathrm{L})$ $\mathrm{Na}_{2} \mathrm{~S}_{2} \mathrm{O}_{8}(5.0 \mathrm{mmol} / \mathrm{L})$ and $\mathrm{CuO}$ microspheres $(0.5 \mathrm{~g} / \mathrm{L})$. (2) Absorption by the above solution after $9 \mathrm{~min}$ of irradiation. Concentration of $\left[\mathrm{Ru}(\mathrm{bpy})_{3}\right]^{2+}$ decreased by $10.2 \%$.

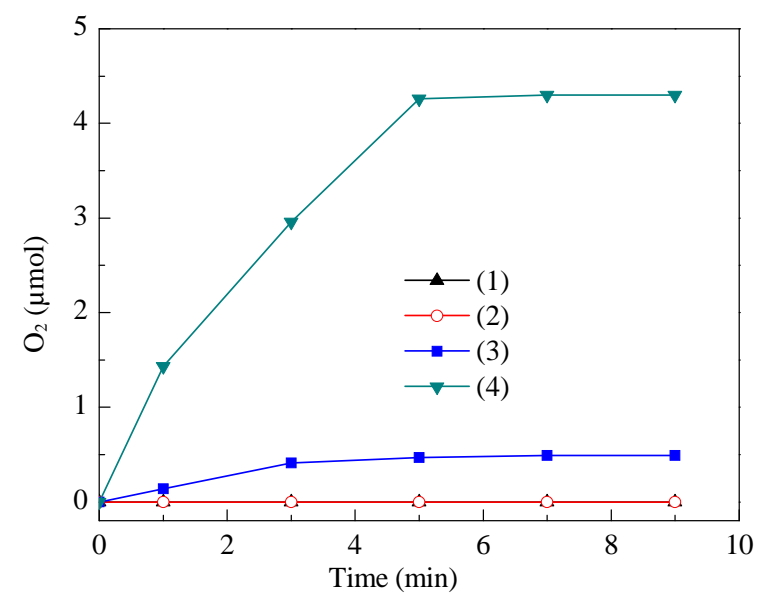

Fig. S15. Kinetics of $\mathrm{O}_{2}$ formation in the photocatalytic system in 80 $\mathrm{mmol} / \mathrm{L}$ sodium borate buffer (initial $\mathrm{pH}$ 8.5), (1)1.0 mmol/L $\left[\mathrm{Ru}(\mathrm{bpy})_{3}\right] \mathrm{Cl}_{2}+0.5 \mathrm{~g} / \mathrm{LCuO}$ microspheres; (2) $5.0 \mathrm{mmol} / \mathrm{L} \mathrm{Na}_{2} \mathrm{~S}_{2} \mathrm{O}_{8}+0.5$ $\mathrm{g} / \mathrm{L} \mathrm{CuO}$ microspheres; (3) $1.0 \mathrm{mmol} / \mathrm{L}\left[\mathrm{Ru}(\mathrm{bpy})_{3}\right] \mathrm{Cl}_{2}+5.0 \mathrm{mmol} / \mathrm{L}$ $\mathrm{Na}_{2} \mathrm{~S}_{2} \mathrm{O}_{8} ; \quad$ (4)1.0 mmol/L $\left[\mathrm{Ru}(\text { bpy) })_{3}\right] \mathrm{Cl}_{2}+5.0 \mathrm{mmol} / \mathrm{L} \quad \mathrm{Na}_{2} \mathrm{~S}_{2} \mathrm{O}_{8}+0.5$ $\mathrm{g} / \mathrm{LCuO}$ microspheres. Conditions: LED lamp $(\lambda \geq 420 \mathrm{~nm})$, total reaction volume $15 \mathrm{~mL}$, overall volume $28 \mathrm{~mL}$, with vigorous agitation using a magnetic stirrer.

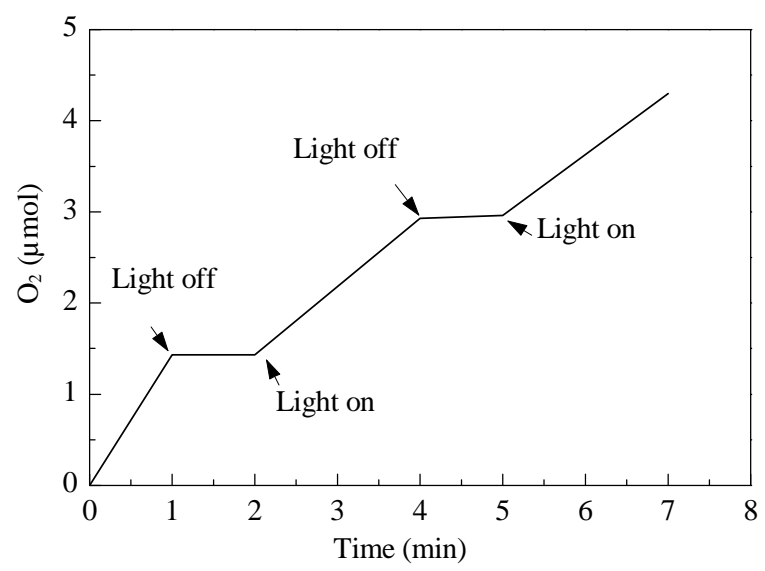

Fig. S16. Light control experiments of the photochemical water oxidation in $80 \mathrm{mmol} / \mathrm{L}$ sodium borate buffer (initial pH 8.5), $1.0 \mathrm{mmol} / \mathrm{L}$ $\left[\mathrm{Ru}(\mathrm{bpy})_{3}\right] \mathrm{Cl}_{2}+5.0 \mathrm{mmol} / \mathrm{L} \mathrm{Na}_{2} \mathrm{~S}_{2} \mathrm{O}_{8}+0.5 \mathrm{~g} / \mathrm{L} \mathrm{CuO} \mathrm{microspheres.}$

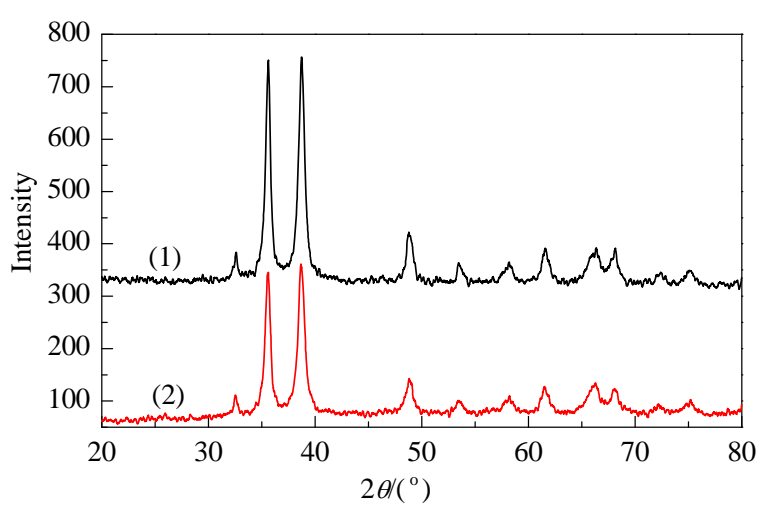

Fig. S17. XRD patterns of fresh (1) and recovered (2) CuO microspheres.

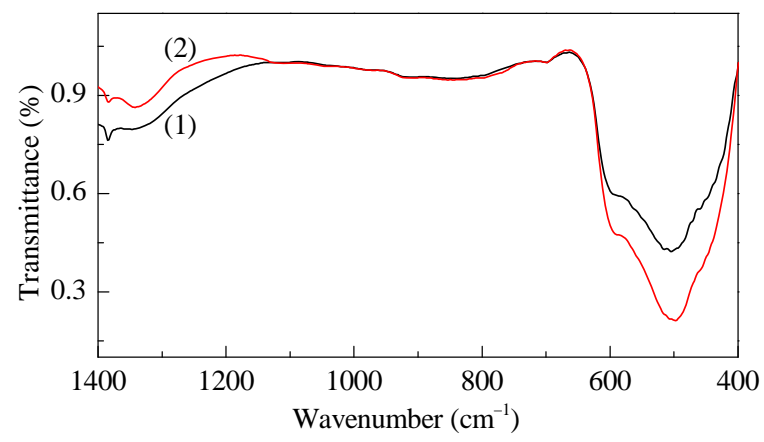

Fig. S18. FT-IR of fresh (1) and recovered (2) CuO microspheres.

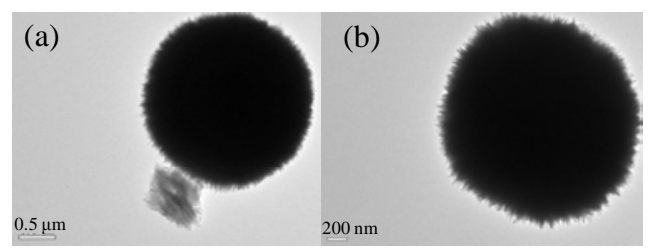

Fig. S19. TEM images of fresh (a) and recovered (b) CuO microspheres.

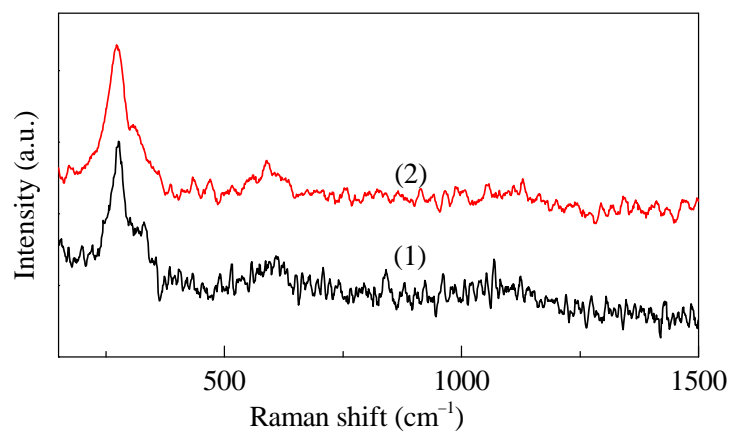

Fig. S20. Raman spectra of fresh (1) and recovered (2) CuO microspheres excited by $514.5 \mathrm{~nm}$ laser.

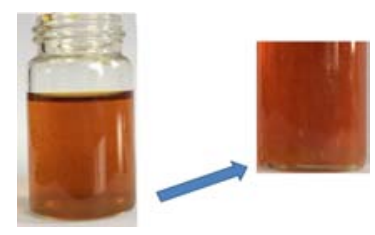

Fig. S21. Solution containing $1.0 \mathrm{mmol} / \mathrm{L}$ of $\left[\mathrm{Ru}(\mathrm{bpy})_{3}\right]^{2+}+5.0 \mathrm{mmol} / \mathrm{L}$ of $\mathrm{Na}_{2} \mathrm{~S}_{2} \mathrm{O}_{8}+0.5 \mathrm{~g} / \mathrm{LCu}\left(\mathrm{NO}_{3}\right)_{2} \cdot 3 \mathrm{H}_{2} \mathrm{O}$ in $\mathrm{pH} 8.5,80 \mathrm{mmol} / \mathrm{L} \mathrm{NaBi}$ after illumination for $9 \mathrm{~min}$. 